\title{
Investigating cost-optimal energy renovation of a multifamily building in Sweden
}

Lina La Fleur, Patrik Rohdin and Bahram Moshfegh

The self-archived postprint version of this journal article is available at Linköping University Institutional Repository (DiVA):

http:/ / urn.kb.se/ resolve?urn=urn:nbn:se:liu:diva-162518

N.B.: When citing this work, cite the original publication.

La Fleur, L., Rohdin, P., Moshfegh, B., (2019), Investigating cost-optimal energy renovation of a multifamily building in Sweden, Energy and Buildings, 203, UNSP 109438.

https:// doi.org/ 10.1016/j.enbuild.2019.109438

Original publication available at:

https:/ / doi.org/ 10.1016/j.enbuild.2019.109438

Copyright: Elsevier

http:// www.elsevier.com/

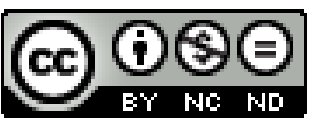




\title{
Investigating cost-optimal energy renovation of a multifamily building in Sweden
}

\author{
Lina La Fleur ${ }^{1, *}$, Patrik Rohdin ${ }^{1}$ and Bahram Moshfegh ${ }^{1,2}$ \\ ${ }^{1}$ Division of Energy Systems, Department of Management and Engineering, Linköping University, Linköping, Sweden \\ ${ }^{2}$ Division of Building, Energy and Environment Technology, Department of Technology and Environment, University of \\ Gävle, Gävle, Sweden \\ *Correspondence: lina.la.fleur@liu.se; tel.: +4613-281156
}

\begin{abstract}
A significant reduction in energy use in the building stock is a major challenge for the future, and doing this in a cost-effective manner is important. This study uses an optimization approach to identify life cycle cost (LCC) optimal energy efficiency measures
\end{abstract} (EEMs) to implement as part of a renovation of a multifamily building in Sweden. The studied building is a multifamily building with a lightweight concrete construction and an exhaust air ventilation system, built in 1961. The optimization tool OPERA-MILP is used. The energy renovation approaches are compared to both the performed energy renovation of the building and a validated dynamic energy simulation model in IDA ICE 4.8. The results show that under the given framework conditions and assumptions it is not cost-optimal to improve the thermal performance of the building envelope or to implement a balanced mechanical ventilation measures to reduce the space heating demand in the building when considering a life cycle of 40 years. Balanced mechanical ventilation system with heat recovery is cost-effective when an energy saving target of $40 \%$ is introduced. The energy renovation of the building has a slightly higher LCC than the cost-optimal level, and it would have been more cost-effective to add more insulation to the façade instead of the attic to achieve the same level of energy saving. A sensitivity analysis has been performed to reveal 
the effect of the discount rate, energy price, cost of EEMs, thermal properties of the building envelope and windows' solar heat gain factors on the LCC.

Keywords: Renovation; LCC; Optimization; Building energy simulation; Multifamily building; Energy use; OPERA-MILP; IDA ICE

\section{Nomenclature}

\begin{tabular}{|c|c|}
\hline$a$ & Number of years \\
\hline$b$ & Number of years \\
\hline BES & Building energy simulation \\
\hline$C E_{1}$ & Inevitable maintenance cost of building envelope, $\mathrm{SEK} / \mathrm{m}^{2}$ \\
\hline$C E_{2}$ & Cost of thermal improvement of building envelope, SEK/m² \\
\hline$C E_{3}$ & Cost of thermal improvement of building envelope, $\mathrm{SEK} / \mathrm{m}^{2} \cdot \mathrm{m}$ \\
\hline$C_{\text {envelope }}$ & $\begin{array}{l}\text { Cost for maintenance and thermal improvement of building envelope, } \\
\mathrm{SEK} / \mathrm{m}^{2}\end{array}$ \\
\hline$C_{\mathrm{HS}}$ & Cost for heating system, SEK \\
\hline COP & Coefficient of power \\
\hline $\mathrm{DH}$ & Degree hours, ${ }^{\circ} \mathrm{Ch}$ \\
\hline EEM & Energy efficiency measure \\
\hline$E_{\text {heating }}$ & Annual heating demand, Wh \\
\hline$E_{\mathrm{IHG}}$ & Internal heat gains from people and appliances, Wh \\
\hline$E_{\text {solar }}$ & Solar heat gains, Wh \\
\hline BMVHR & Balanced mechanical ventilation with heat recovery system \\
\hline$H S_{1}$ & Cost for heating system, SEK \\
\hline$H S_{2}$ & Cost for heating system, SEK/kW \\
\hline$H S_{3}$ & Cost for support system for heating system, SEK/kW \\
\hline LCC & Life cycle cost \\
\hline LLCC & Lowest life cycle cost \\
\hline$N$ & Non-recurring cost, SEK \\
\hline OPERA-MILP & OPtimal Energy Retrofit Advisory-Mixed Integer Linear Programming \\
\hline$P$ & Maximum power demand, $\mathrm{kW}$ \\
\hline$P V$ & Present value, SEK \\
\hline$Q_{\text {infiltration }}$ & Infiltration heat losses, W/K \\
\hline$Q_{\text {transmission }}$ & Building envelope transmission losses, W/K \\
\hline$Q_{\text {ventilation }}$ & Ventilation heat losses, W/K \\
\hline$r$ & Discount rate, $\%$ \\
\hline$r_{\mathrm{a}}$ & Adjusted discount rate, $\%$ \\
\hline$q$ & Annual increase in energy price \\
\hline$R$ & Annually recurring cost, SEK \\
\hline $\mathrm{RV}$ & Residual value, SEK \\
\hline$t$ & Insulation thickness, $\mathrm{m}$ \\
\hline
\end{tabular}




\section{Introduction}

The built environment represents around $40 \%$ of the final energy use in the European Union. The European Commission estimates that around 35\% of European buildings are over 50 years old and that $75 \%$ of all European buildings are energy inefficient compared to modern standards [1]. A substantial part of the Swedish housing stock was constructed between 1961 and 1975 [2], and it is estimated that around 75\% of these buildings are in need of renovation in some form [3]. Accordingly, the renovation of buildings is a central aspect of reducing the energy use and carbon footprint of the European building stock. The Energy Performance of Buildings Directive urges cost-effective energy savings in the existing building stock, and leaves it to the member states to define the requirements for building performance [4]. The requirements should lead to a cost-optimal balance between costs for energy and investments needed to reduce energy use over the life cycle of the building.

Life cycle cost (LCC) analysis in a building and renovation context is an assessment based on current and future costs for construction, installation, maintenance and operation of a building during its life cycle [5]. Several studies use an LCC approach when studying energy efficiency measures (EEMs) in buildings [6-9] and many authors highlight the potential of optimization approaches for achieving cost-effective renovation [6,7,10-14]. Gluch and Gustavsson showed in a study of Swedish organizations working with property management that respondents were generally positive towards LCC in a renovation context, but although it was discussed to a large degree it was not implemented to the same extent [15]. The cost-effectiveness of renovation measures and the most cost-effective renovation approach vary between different building types. Ekström et al. use an LCC assessment to 
identify cost-effective strategies for passive house renovation of single family buildings and find that installing an exhaust air heat pump is the most cost-effective measure, while changing to better windows is the least cost-effective measure [16]. In a study of historic buildings in Visby, Sweden, Milic et al. also found that window replacement was often not cost-effective due to high initial investment costs [7]. Niemelä et al. find that it is not a costoptimal measure to insulate the façade or to invest in a balanced ventilation system in typical exhaust ventilated Finnish brick apartment buildings constructed in the 1960s [11]. Instead, Niemelä et al. showed that a heat pump solution was the most cost-effective investment. In a study of naturally ventilated Estonian brick apartments, changing to a balanced mechanical ventilation system with heat recovery was shown to increase global cost although allowing for better indoor air quality [17].

Buildings with relatively good energy performance before renovation have lower costeffectiveness of energy saving measures compared to buildings with significant heat losses before renovation. Kuusk et al. found that the cost optimal level of renovation measures in Estonian brick apartments with typical energy performance for Eastern European apartments was close to the requirement for new buildings with regard to energy efficiency [17]. In studies of buildings with poor thermal performance prior to renovation, insulation measures of the climate envelope are found to be cost-effective $[6,7,17]$. In a case study of a poorly insulated multifamily building from the 1890s, Liu et al. show that the lowest possible LCC would be achieved by insulation of the façade, insulation of the attic and weather stripping, which meant a reduction in space heating demand of $28 \%$ [6]. 
A study of drivers and barriers for energy efficiency measures in a renovation context showed that efficiency measures are perceived as expensive and that the planning phase lacked a focus on EEMs and LCC considerations [18]. The study also showed that there was a lack of energy calculation and that the selected energy renovation measures were based on past experiences and a standard approach, rather than on an analysis of the cost-effectiveness of EEMs. Reindl [19] found through interviews in a case study of two major renovations in Sweden that although energy efficiency was ranked as the second most important aspect of the renovation, it was not considered to a large extent during the renovation planning phase and there was a lack of a clear goals for energy efficiency improvements.

This study addresses the energy efficiency aspects of energy renovations by comparing a renovation that was performed in a Swedish multifamily building with LCC optimal energy renovation of the building. The aim of the study is to identify cost-optimal combinations of EEMs with different energy saving targets for a multifamily building constructed in the early 1960s. A life cycle cost optimization approach is used, and the LCC optimization is carried out using the tool OPERA-MILP which builds on a quasi-steady state heat balance calculation for predicting space heating demand in the building. The predicted heating demand is validated with a dynamic whole building energy simulation in the software IDA ICE. The IDA ICE model has previously been empirically validated with regard to its accuracy in predicting both indoor air temperature and monthly heat demand, see [20]. The sensitivity of the results is studied with regard to differences in thermal properties of the building prior to energy renovation, energy costs and discount rate, cost of EEMs, and the windows' solar heat gains factor. 
The study introduces an approach to identifying suitable EEMs for a building that requires less modelling and computational time than conventional dynamic modelling of building space heating demand, and allows for the evaluation of different measures that are suitable with different energy saving objectives for an energy renovation. The approach is suitable in the planning phase of energy renovation, and can be performed using basic geometry and thermal properties of the building.

\section{Case study}

The studied multifamily building is located in Linköping, Sweden, and represents a common building type in the Swedish building stock. The building (see Figure 1) was constructed in 1961 and has a lightweight concrete construction, and originally had an exhaust ventilation system. The building has previously been studied using field measurements, questionnaires and dynamic simulations before and after it underwent renovation in 2014 [20-22]. The building has a heated area ${ }^{1}$ of $1072.5 \mathrm{~m}^{2}$ and twelve apartments. The building is connected to the district heating network and has been heated with district heating both prior to and after the renovation.
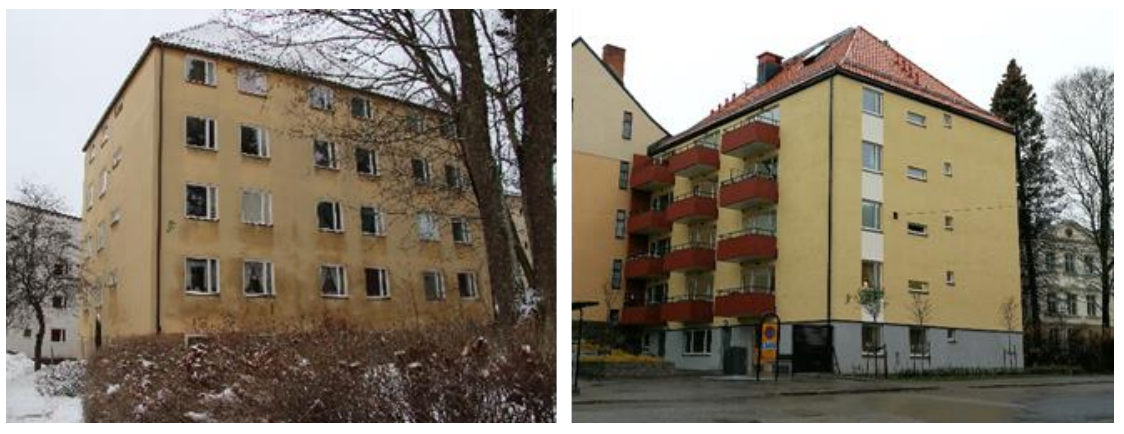

Figure 1 . The case study building before (left) and after (right) it underwent renovation.

\footnotetext{
${ }^{1}$ Internal floor area of building (including attic and basement) heated to more than $10^{\circ} \mathrm{C}$.
} 
The original construction and $U$-values are seen in Table 1 . When the building was renovated, a new balanced mechanical ventilation with heat recovery system (hereinafter called as BMVHR system) was installed, $100 \mathrm{~mm}$ of additional mineral wool insulation was added to the walls and $180 \mathrm{~mm}$ of additional insulation was added to the attic. The original roof construction was insulated with $40 \mathrm{~mm}$ cork, which was replaced with the same amount of mineral wool insulation when the roofing tiles were replaced and the roof foundation was repaired as part of the renovation. The heat recovery efficiency of the BMVHR system was measured at $57.4 \%$ during one month of operation [20].

Table 1. Original constriction of the building, area and $U$-values of building segments.

\begin{tabular}{|c|c|c|c|c|c|}
\hline Segment & $\begin{array}{l}\text { Area } \\
\left(\mathbf{m}^{2}\right)\end{array}$ & Original construction & Renovated construction & $\begin{array}{l}U \text {-value }{ }^{1} \\
\text { before } \\
\text { renovation } \\
\left(\mathbf{W} / \mathbf{m}^{2} \cdot \mathbf{K}\right)\end{array}$ & $\begin{array}{l}U \text {-value }{ }^{1} \\
\text { after } \\
\text { renovation } \\
\left(\mathbf{W} / \mathbf{m}^{2 \cdot} \cdot \mathbf{K}\right)\end{array}$ \\
\hline Walls $^{1}$ & 569.9 & $\begin{array}{l}0.01 \mathrm{~m} \text { gypsum, } 0.25 \mathrm{~m} \\
\text { lightweight concrete, cladding }\end{array}$ & $\begin{array}{l}0.01 \mathrm{~m} \text { gypsum, } 0.25 \mathrm{~m} \\
\text { lightweight concrete, } 0.1 \mathrm{~m} \\
\text { mineral wool, cladding }\end{array}$ & $0.43^{2}$ & $0.20^{2}$ \\
\hline Roof $^{1}$ & 23.1 & $\begin{array}{l}0.15 \mathrm{~m} \text { concrete, } 0.04 \mathrm{~m} \text { cork, } \\
\text { roofing tile }\end{array}$ & $\begin{array}{l}0.15 \mathrm{~m} \text { concrete, } 0.04 \mathrm{~m} \text { mineral } \\
\text { wool, roofing tile }\end{array}$ & $0.91^{2}$ & $0.72^{2}$ \\
\hline Windows north & 52.6 & 3 -pane clear glass ${ }^{3}$ & 3-pane, low emissivity glazing ${ }^{4}$ & 1.9 & 1.1 \\
\hline Windows east & 2.6 & 3-pane clear glass ${ }^{3}$ & 3-pane, low emissivity glazing ${ }^{4}$ & 1.9 & 1.1 \\
\hline Windows south & 40.0 & 3-pane clear glass ${ }^{3}$ & 3-pane, low emissivity glazing ${ }^{4}$ & 1.9 & 1.1 \\
\hline Windows west & 17.6 & 3-pane clear glass ${ }^{3}$ & 3-pane, low emissivity glazing ${ }^{4}$ & 1.9 & 1.1 \\
\hline Floor & 216.5 & $\begin{array}{l}0.2 \mathrm{~m} \text { concrete, } 0.1 \mathrm{~m} \\
\text { insulation, ground }\end{array}$ & $\begin{array}{l}0.2 \mathrm{~m} \text { concrete, } 0.1 \mathrm{~m} \\
\text { insulation, ground }\end{array}$ & $0.2^{2}$ & $0.2^{2}$ \\
\hline Attic & 194.5 & $\begin{array}{l}0.05 \mathrm{~m} \text { concrete, } 0.12 \mathrm{~m} \text { mineral } \\
\text { wool, } 0.2 \mathrm{~m} \text { concrete }\end{array}$ & $\begin{array}{l}0.05 \mathrm{~m} \text { concrete, } 0.3 \mathrm{~m} \text { mineral } \\
\text { wool, } 0.2 \mathrm{~m} \text { concrete }\end{array}$ & $0.27^{2}$ & $0.12^{2}$ \\
\hline \multicolumn{6}{|c|}{$\begin{array}{l}{ }^{1} \text { Ceiling of top floor partly faces the roof and partly the attic. The roof area represents the external area of the apartments' enclosing area, see } \\
\text { Figure 2. Equivalent } U \text {-value } 0.45 \mathrm{~W} / \mathrm{m}^{2} \cdot \mathrm{K} \text {. } \\
{ }^{2} U \text {-values calculated in accordance with ISO 6946-Building components and building elements-Thermal resistance and thermal } \\
\text { transmittance [23]. Values for thermal conductivity }(\mathrm{W} / \mathrm{m} \cdot \mathrm{K}) / \mathrm{density}\left(\mathrm{kg} / \mathrm{m}^{3}\right) / \mathrm{specific} \text { heat capacity }(\mathrm{J} / \mathrm{kg} \cdot \mathrm{K}): \text { lightweight concrete: } \\
0.12 / 500 / 1050, \text { mineral wool: } 0.036 / 20 / 750 \text {, cladding: } 0.8 / 1800 / 790, \text { concrete: } 1.7 / 2300 / 880, \text { cork: } 0.05 / 100 / 950 \\
\left.{ }^{3} g \text {-value } 0.68 \text {. Standard } U \text {-values for windows including frames (IDA ICE version } 4.8\right) \\
{ }^{4} g \text {-value } 0.43 \\
{ }^{5} \text { Ground properties and floor } U \text {-value calculated in accordance with ISO } 13370 \text {-Thermal performance of buildings- Heat transfer via the } \\
\text { ground-Calculation methods [24] }\end{array}$} \\
\hline
\end{tabular}

The building has five floors with three apartments on each of the top four floors, see

Figure 2. The ceiling of the top floor partly faces the roof and partly the attic, which can be 
seen in the cross section. The building had a total air exchange rate of $0.96 \mathrm{~h}^{-1}$ before the renovation, where $0.14 \mathrm{~h}^{-1}$ was infiltration [20].
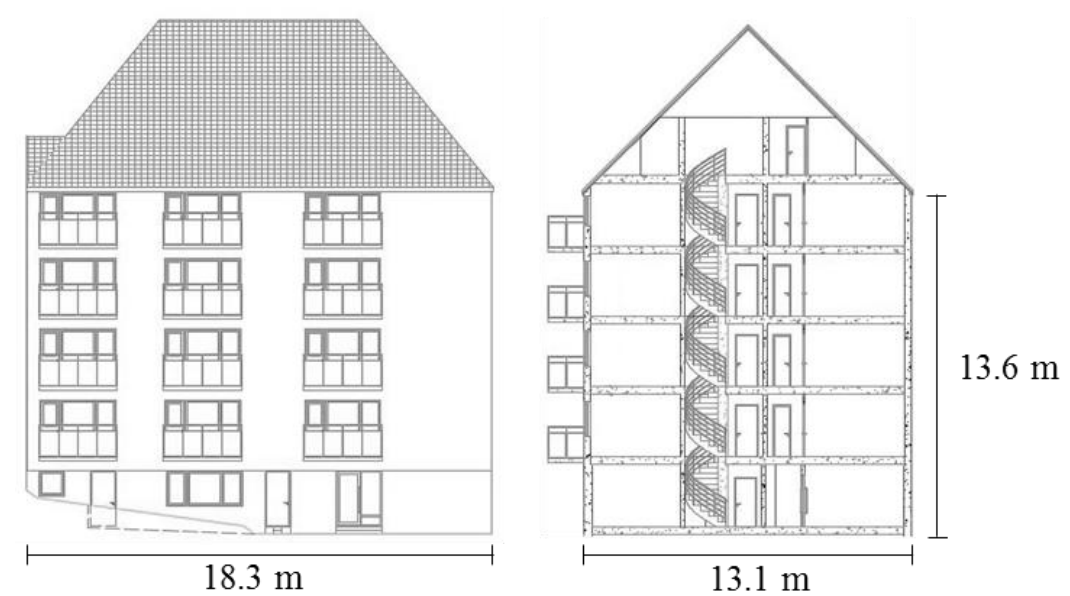

Figure 2. Façade facing south (left) and cross section of the building (right).

\section{Methodological approach}

The analysis is based on LCC optimization using the optimization tool OPERA-MILP (OPtimal Energy Retrofit Advisory-Mixed Integer Linear Programming). The input data to OPERA-MILP consist of the existing building geometry, $U$-values, air exchange rates from ventilation and infiltration, climate data for the location, and internal heat gains. The input data is used to calculate the space heating demand with a quasi-steady state heat balance calculation. In addition to this, the costs of different EEMs and the characteristics of these measures (such as thermal conductivity of insulation or reductions in air exchange rates) as well as energy tariffs are input to OPERA-MILP. OPERA-MILP then finds the lowest possible LCC (LLCC) by implementing EEMs. The total LCC is calculated at present value and the annual space heating demand after implementing the EEMs is calculated with the quasi-steady state heat balance. 
A dynamic whole building energy simulation (BES) model in IDA ICE has been used with the same input data to validate the results from OPERA-MILP, by comparing the simulated space heating demand after implementing the suggested EEMs with the space heating demand calculated with the quasi-steady state heat balance approach. The IDA ICE model has been empirically validated with measured data prior to this study in [20]. An overview of the methodological approach is seen in Figure 3.

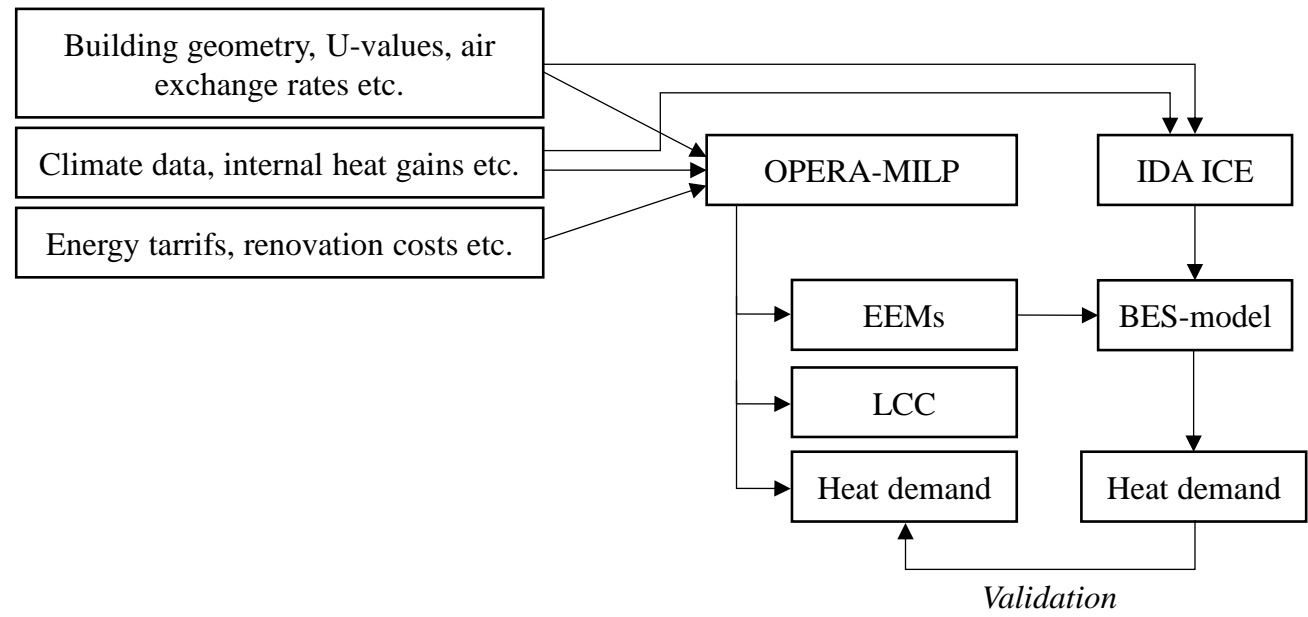

Figure 3. Overview of methodological approach and tool chain.

\subsection{Life cycle cost optimization}

Life cycle cost analysis is a method of summarizing all costs that occur during the life cycle of a product, and is commonly used to evaluate different investment alternatives. Costs will occur on different temporal occasions in the life cycle and all costs are therefore discounted to present costs [5]. The net present value is the most common approach. For buildings, the costs are related to investment in construction or technical installation, operation (i.e. space heating demand) and maintenance during the selected life cycle. Basic maintenance of a building is required, such as painting façades or replacing windows, and has no or little effect on the operation costs of the building. The owner of the building can 
also invest in EEMs, such as thermal insulation or installing better windows, which lower the space heating demand and thus the operation cost. For the EEM to be a profitable investment, the cost of the investment has to be lower than the cost savings for building operation during the life cycle of the building. To achieve the lowest LCC for a building, an optimization approach can be useful when deciding on an energy renovation approach.

The building energy renovation optimization tool OPERA-MILP was developed to identify EEMs that have the lowest combined LCC during the selected life cycle. OPERAMILP was developed at Linköping University, Sweden, in the 1990s to serve as a tool for identifying suitable energy renovation strategies for multifamily buildings [25]. Since then, the tool has been used in several studies of multifamily buildings [26-29] as well as historic buildings $[6,30,31]$.

The renovation of the building consists of maintenance and EEMs. The cost of maintaining the building is inevitable in order to keep the building in an acceptable condition. The cost of EEMs on the other hand only occurs if it is profitable to invest in them. The inevitable maintenance and EEMs for the building are summarized in Table 2.

Table 2. Inevitable renovation measures and EEMs of different building segments.

\begin{tabular}{|c|c|c|}
\hline & Inevitable maintenance measures & Energy efficiency measures \\
\hline Façade & Façade cleaning and repainting of façade & $\begin{array}{l}\text { Insulation with mineral wool, new } \\
\text { façade plaster }\end{array}$ \\
\hline Attic and roof & None & Insulation of attic with mineral wool \\
\hline Windows & $\begin{array}{l}\text { New wood framed windows with } U \text {-value } 1.9 \\
\mathrm{~W} / \mathrm{m}^{2} \cdot \mathrm{K}\end{array}$ & $\begin{array}{l}\text { New aluminum framed windows with } \\
U \text {-value } 1.1 \text { or } 0.8 \mathrm{~W} / \mathrm{m}^{2} \cdot \mathrm{K}\end{array}$ \\
\hline $\begin{array}{l}\text { Ventilation } \\
\text { system }\end{array}$ & None & $\begin{array}{l}\text { Balanced ventilation system with heat } \\
\text { recovery }\end{array}$ \\
\hline
\end{tabular}

The LCC for the renovated building is the discounted sum of the cost of maintaining the building ( $\mathrm{LCC}_{\text {maintenance }}$ ), the cost of installing a heating system ( $\mathrm{LCC}_{\text {heating system }}$ ), the cost of investment in EEMs (LCC $\mathrm{EEM}_{\mathrm{E}}$ ) that are implemented in the building to reduce space 
heating demand, and the operation cost of heating the building during the entire life cycle ( $\left.\mathrm{LCC}_{\text {operation}}\right)$, minus the residual value $(\mathrm{RV})$ of any investment that has a value after the life cycle, see Equation 1.

$$
\mathrm{LCC}_{\text {total }}=\mathrm{LCC}_{\text {maintenance }}+\mathrm{LCC}_{\text {heating system }}+\mathrm{LCC}_{\mathrm{EEM}}+\mathrm{LCC}_{\text {operation }}-\mathrm{RV}
$$

The LCC is the sum of the present value (PV) of the investments made in the building during the entire life cycle and the present value of annually recurring costs in the building. The present value of investments in maintenance of the building, heating system and EEMs are non-recurring annually during the life cycle and are calculated in Equation 2. A new investment is made if the technical lifetime of the investment is shorter than the selected life cycle.

$$
P V=N \times(1+r)^{-a}
$$

where $N$ is an investment that does not occur annually, $r$ is the discount rate and $a$ is the number of years until the cost occurs. The current cost levels are used in this analysis. For the cost that recurs annually, in this case space heating, the present value of the costs during the whole life cycle is calculated in accordance with Equation 3.

$$
P V=R \times \frac{1-(1+r)^{-b}}{r}
$$

where $R$ is the annually recurring cost of space heating the building, and $b$ is the number of years that $R$ occurs during the life cycle. The heating demand for the building is calculated with a quasi-steady state heat balance calculation with twelve time steps.

An increase in energy price can be included using a adjusted discount rate, $r_{a}$, using Equation 4 [32]. 


$$
r_{a}=\frac{r-q}{1+q}
$$

Where $q$ is the annual increase in energy price.

OPERA-MILP is based on mixed integer linear programming and uses linear cost functions for investment in EEMs in a building [32,33]. The EEMs consist of insulation of the building envelope and reduction of air exchange rate. The total cost for maintenance and thermal improvement of the building envelope (walls, floor, attic and windows), $C_{\text {envelope }}$ $\left(\mathrm{SEK} / \mathrm{m}^{2}\right)$, is calculated in Equation 5.

$$
C_{\text {envelope }}=C E_{1}+\left(C E_{2}+C E_{3} \times t\right)
$$

where $C E_{1}$ is the inevitable maintenance cost $\left(\mathrm{SEK} / \mathrm{m}^{2}\right), C E_{2}$ is costs related to insulating the envelope independent of the insulation thickness $\left(\mathrm{SEK} / \mathrm{m}^{2}\right), C E_{3}$ is costs related to insulating the envelope dependent on and linear to the insulation thickness $\left(\mathrm{SEK} / \mathrm{m}^{2} \cdot \mathrm{m}\right)$, and $t$ is the thickness of the insulation $(\mathrm{m})$. The cost function for insulation of the building envelope is visualized in Figure 4. For windows, $C E_{3}$ is not applicable and instead OPERA-MILP allows for different window types with different $U$-values and $C E_{1}$ and $C E_{2}$ costs.

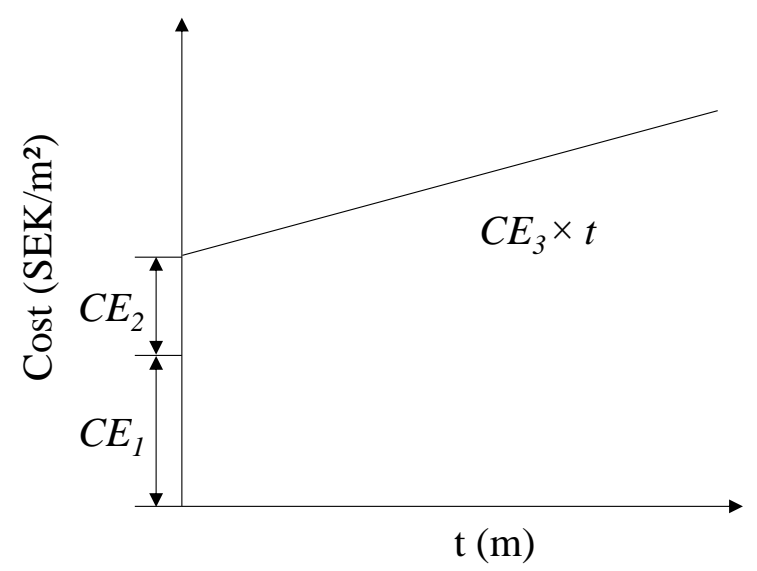

Figure 4. Cost function for insulation of the building envelope. 
OPERA-MILP includes four heating supply systems in the optimization: district heating, ground source heat pump, wood boiler and an electricity boiler with individual tariffs. A combination of two or more heating supply systems can be implemented if the LCC is reduced. The investment cost for the heating system, $C_{\mathrm{HS}}(\mathrm{SEK})$, is dependent on the maximum installed power of the system and is calculated in Equation 6.

$$
C_{H S}=H S_{1}+H S_{2} \times P+H S_{3} \times P
$$

where $H S_{1}$ is the cost of installing a new heating system regardless of maximum power (SEK), $H S_{2}$ is the cost of installing a new heating system and is linear to the maximum power of the heating system $(\mathrm{SEK} / \mathrm{kW}), P$ is the maximum power of the heating system $(\mathrm{kW})$, and $H S_{3}$ is costs related to systems needed in connection with the heating system, such as pipes, a chimney or a bore hole (SEK). The heating system $\left(H S_{1}\right.$ and $\left.H S_{2}\right)$ and related systems $\left(H S_{3}\right)$ can have different technical lifetimes.

In addition to insulation measures, OPERA-MILP can reduce heat losses by reducing air leakage in the building. Originally, this was implemented to evaluate whether weather stripping is a profitable measure. The cost and at what interval the measure is needed is given per window, and the total decrease in air exchange rate is given for the entire building. This function can also be used for ventilation measures, where the cost is given for one new ventilation system and the reduction in air exchange rate corresponds to the heat exchanger efficiency.

\subsection{Predicting building space heating demand}

Accurate prediction of building space heating demand is essential for estimations of costs during the operative phase of the building. Different approaches with different levels 
of detail, time requirements and accuracy exist and can be used. Space heating demand can be calculated by hand or in simple calculation tools using degree hours for the current location and building balance temperature. Although this static calculation approach requires little time and effort, the accuracy is relatively low. Aspects that are central to a building's heat losses and space heating demand, such as wind-driven infiltration and heat gains from solar radiation, are difficult to include in static calculation approaches. At the other end of the spectrum, the building space heating demand can be predicted with a dynamic simulation with a higher level of detail and accuracy [34-37]. This requires significantly more knowledge about the building, data, time and effort in model creation, as well as user skill [35].

The cost of heating the building included in OPERA-MILP is based on a quasi-steady state heat balance calculation with monthly time steps for one reference year. OPERA-MILP summarizes the heat losses from building envelope transmission, ventilation and infiltration based on envelope areas, $U$-values and average air exchange rates. Internal heat gains from appliances, occupants and solar radiation are subtracted from the monthly space heating demands. The annual space heating demand, $E_{\text {heating }}(\mathrm{Wh})$, is calculated using Equation 7.

$$
E_{\text {heating }}=\left(Q_{\text {transmission }}+Q_{\text {ventilation }}+Q_{\text {infiltration }}\right) \times D H-E_{I H G}-E_{\text {solar }}
$$

where $Q_{\text {transmission }}$ is the envelope transmission losses $(\mathrm{W} / \mathrm{K}), Q_{\text {ventilation }}$ is losses from ventilation $(\mathrm{W} / \mathrm{K}), Q_{\text {infiltration }}$ is losses from infiltration $(\mathrm{W} / \mathrm{K}), \mathrm{DH}$ is the degree hours $\left({ }^{\circ} \mathrm{Ch}\right), E_{\mathrm{IHG}}$ is the internal heat gain from appliances and occupants (Wh), and $E_{\text {solar }}$ is the useful solar radiation (Wh). The degree hours are calculated as the difference in indoor 
temperature and mean monthly outdoor temperature multiplied by the hours during the same month.

The quasi-steady state heat balance calculation gave an annual space heating demand before renovation and implementation of EEMs of $121.7 \mathrm{MWh}$ per year $\left(113.5 \mathrm{kWh} / \mathrm{m}^{2} \cdot \mathrm{y}\right)$, which serves as the reference case for the energy saving targets.

\subsubsection{Validation of quasi-steady state heat balance}

A dynamic simulation of the space heating demand was carried out in IDA ICE version 4.8 and was used to validate the results from OPERA-MILP. IDA ICE is a dynamic whole building energy simulation program that has been validated in accordance with ASHRAE Standard 140-2004 [38] and CEN Standard EN 15255-2007 and 15265-2007 [39], CEN Standard EN 13791 [40], and has shown good agreement with test cell measurements performed as part of IEA's SHC Task 34 [41]. The model of this particular building has been validated with regard to its ability to predict both an accurate indoor climate and space heating demand $[20,21]$. The model predicted the indoor air temperature at zone level with maximum standard deviation of $0.4^{\circ} \mathrm{C}$ during winter, and the difference between predicted and meausured space heating demand was $3.7 \%$ before renovation and $5.6 \%$ after renovation [20]. When a validation of modelled space heating demand is carried out with empirical measurements, a model variation from measured data of less than $5 \%$ to $15 \%$ is desirable for models with a time step of one month [42]. The model can be seen in Figure 5. 


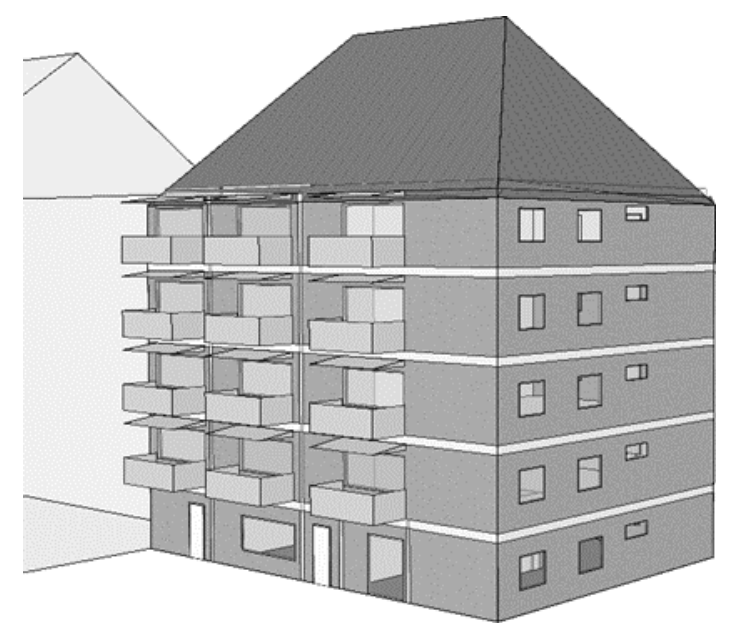

Figure 5. The building model in IDA ICE version 4.8 .

\subsection{Input data and assumptions}

The building geometry and $U$-values used for calculation of space heating demand and costs were presented in Table 1. The indoor temperature in the building is assumed to be $21^{\circ} \mathrm{C}$. Because of the geometry of the ceiling on the top floor, the equivalent $U$-value was used for the wall segment. Thermal bridges are included and are assumed to represent $10 \%$ of the building envelope transmission losses. The building characteristics before the renovation serve as the reference case. The space heating demand and costs for the reference case include maintaining the same thermal properties of the building and only performing inevitable maintenance. The LCC is calculated with district heating as the energy supply system. A comparison is made with a ground source heat pump as the energy supply system.

The internal heat gains from people and appliances were based on findings from the Swedish SVEBY program [43], which is a development program for understanding energy use and user patterns in buildings. The heat gains from appliances and occupancy are summarized for the entire month and will thus be useful as long as there is a heat deficit to cover during the month. Domestic hot water (DHW) use has been excluded from all calculations, since it is not affected by the EEMs included in the optimization. The maximal 
power demand of the heating system is thus calculated for the space heating demand. To estimate the useful fraction of the solar heat gains, the heat balance from the empirically validated IDA ICE model was used [20,21]. The useful fraction represents heat from solar radiation that replaces active space heating of the building. The reference case has slightly higher solar gains than the renovated cases because of the higher window $g$-value. It should be noted that the useful fraction of the solar radiation will decrease when the building has lower heat losses, but it gives a relatively close estimate even at higher building energy performance levels.

The LCC is calculated and optimized for a period of 40 years, which is considered a normal lifetime for components related to the building envelope, such as insulation or windows [44], and thus the time until a new major renovation of the building will be needed. The discount rate is $5 \%$, which has been used in several studies of the life cycle costs of energy renovation $[6,7,9,45,46]$. Insulation of the building is possible on the façade and in the attic with a maximum thickness of $400 \mathrm{~mm}$. The option of replacing the windows with new aluminum frame windows with a glazing $U$-value of $1.1 \mathrm{~W} / \mathrm{m}^{2} \cdot \mathrm{K}$ or $0.8 \mathrm{~W} / \mathrm{m}^{2} \cdot \mathrm{K}$ was included. Both windows are assumed to have the same solar heat gain factor ( $g$-value $=0.43$ ). The reference case includes installing new wood framed windows with a $U$-value of $1.9 \mathrm{~W} / \mathrm{m}^{2} \cdot \mathrm{K}$ and a $g$-value of 0.68 . The cost is assumed to be similar to modern window types, but the lifetime is shorter (30 years) compared to windows with an aluminum frame. Hence, the window type will not be optimal in any of the optimized cases. The exhaust air ventilation system can be replaced with a BMVHR system. The efficiency of the heat recovery is assumed to be the efficiency of the system installed in the actual renovation 
$(57.4 \%)$ [20]. The reduction in ventilation heat losses corresponds to a reduction in air exchange rate of $0.45 \mathrm{~h}^{-1}$. In addition to the lowest possible LCC for the building, the LCC with energy saving targets ranging between $10 \%$ and $70 \%$ reduction in space heating demand is analyzed. A higher reduction in space heating demand than the energy saving targets is allowed. If a higher energy saving than the target is optimal, the LCC for the actual target is calculated by removing the measures with the highest increase in LCC per reduced $\mathrm{kWh}$. Note that these combinations of EEMs are not optimal and are calculated to illustrate how different energy saving targets set for an energy renovation can affect the selected measures and LCC.

\subsubsection{Renovation costs}

Renovation costs vary between buildings, building locations and contractors. The Swedish database Wikells Sektionsfakta was used to find costs for renovation measures and installations. Wikells Byggberäkningar AB is a Swedish company that offers a database with costs for construction and labor for building parts and technical installations in buildings, and is a common database for cost calculations for new buildings and renovations in Sweden [47]. The costs per square meter for the attic, façade and windows, as well as the heating system, are summarized in Table 3. Maintenance and renovation of a building includes additional costs to those included in this analysis, but renovation where there is no option to improve energy efficiency, such as esthetic improvements of apartments, has been excluded.

The attic has no inevitable maintenance cost $\left(C E_{1}\right)$. The inevitable maintenance cost for the façade includes cleaning and painting it. The cost of EEMs, $C E_{2}$ and $C E_{3}$ for the attic and façade are linearized based on the cost of insulation thickness ranging between 50 and 
$200 \mathrm{~mm}$. The cost for the attic does not include costs for refurbishing the attic. The inevitable costs for windows are based on window replacement with low thermal performance windows compared to today's standard. The cost increases if a better performing window is installed. The cost of a new heating system is linearized based on district heating exchangers with a thermal power ranging between 40 and $100 \mathrm{~kW}$ and a ground source heat pump ranging between 22 and $60 \mathrm{~kW}$. The costs for ventilation measures are closely related to the layout and construction of a building and have been calculated for the current building. The cost of installing ducts, shafts, room air inlets and outlets and a central fan unit with a capacity of around $600 \mathrm{l} / \mathrm{s}$ unit is $1.25 \mathrm{MSEK}^{2}$. The electricity cost for operation is $0.07 \mathrm{MSEK}$ during the life cycle. The installations made in the apartment are assumed to last for 40 years. An alternative cost for the BMVHR system is included, where additional maintenance is performed and the lifetime of apartment installations is assumed to be 20 years and thus need to be replaced. This means an additional cost of 0.11 MSEK at current costs levels.

Table 3. Costs for different renovation measures and heating systems (year 2019)

\begin{tabular}{|c|c|c|c|c|c|}
\hline $\begin{array}{l}\text { Insulation } \\
\text { measures }\end{array}$ & $\begin{array}{l}C E_{1} \\
\left(\mathrm{SEK} / \mathbf{m}^{2}\right)\end{array}$ & $\begin{array}{l}C E_{2} \\
\left(\mathrm{SEK} / \mathrm{m}^{2}\right)\end{array}$ & $\begin{array}{l}C E_{3} \\
\left(\mathrm{SEK} / \mathbf{m} \cdot \mathbf{m}^{2}\right)\end{array}$ & $\begin{array}{l}\text { Thermal } \\
\text { conductivity } \\
(\mathbf{W} / \mathbf{m} \cdot \mathbf{K})\end{array}$ & $\begin{array}{l}\text { Technical } \\
\text { lifetime }\end{array}$ \\
\hline $\begin{array}{l}\text { Attic (max } 400 \\
\text { mm) }\end{array}$ & 0 & 248 & 544 & 0.037 & 40 years \\
\hline $\begin{array}{l}\text { Façade (max } 400 \\
\text { mm) }\end{array}$ & 409 & 1256 & 1283 & 0.037 & 40 years \\
\hline $\begin{array}{l}\text { Window } \\
\text { measures }\end{array}$ & $\begin{array}{l}C E_{1} \\
\left(\mathrm{SEK} / \mathrm{m}^{2}\right)\end{array}$ & $\begin{array}{l}C E_{2} \\
\left(\mathrm{SEK} / \mathrm{m}^{2}\right)\end{array}$ & $C E_{3}$ & $\begin{array}{l}\text { Window } U \text { - } \\
\text { value } \\
\left(\mathrm{W} / \mathrm{m}^{2} \cdot \mathrm{K}\right)\end{array}$ & $\begin{array}{l}\text { Technical } \\
\text { lifetime }\end{array}$ \\
\hline $\begin{array}{l}\text { Original } \\
\text { windows }{ }^{1}\end{array}$ & 7895 & 0 & - & 1.9 & 30 years \\
\hline Window type $1^{2}$ & 7895 & 441 & - & 1.1 & 40 years \\
\hline Window type $2^{2}$ & 7895 & 1367 & - & 0.8 & 40 years \\
\hline Heating system & $\begin{array}{l}H S_{1} \\
(\mathrm{SEK})\end{array}$ & $\begin{array}{l}H S_{2} \\
(\mathrm{SEK} / \mathrm{kW})\end{array}$ & $\begin{array}{l}H S_{3} \\
(\mathrm{SEK} / \mathrm{kW})\end{array}$ & $\begin{array}{l}\text { Heating system } \\
\text { average } \mathrm{COP}^{4}\end{array}$ & $\begin{array}{l}\text { Technical } \\
\text { lifetime }\end{array}$ \\
\hline $\begin{array}{l}\text { District heating } \\
\text { exchanger }\end{array}$ & 33336 & 53 & 535 & 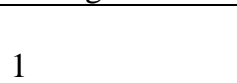 & 20 years $^{3}$ \\
\hline $\begin{array}{l}\text { Ground source } \\
\text { heat pump }\end{array}$ & 72327 & 4522 & 27328 & $3^{5}$ & 20 years $^{3,6}$ \\
\hline
\end{tabular}

\footnotetext{
${ }^{2}$ Exchange rate 1 Euro $=10.3$ SEK.
} 


\begin{tabular}{|c|c|c|c|c|c|}
\hline $\begin{array}{l}\text { Ventilation } \\
\text { measures }\end{array}$ & $\begin{array}{l}\text { Normal } \\
\text { maintenance } \\
(\mathrm{MSEK})\end{array}$ & $\begin{array}{l}\text { Additional } \\
\text { maintenance } \\
\text { (MSEK) }\end{array}$ & Operation (MSEK) & $\begin{array}{l}\text { Corresponding } \\
\text { reduction in air } \\
\text { exchange rate }\end{array}$ & $\begin{array}{l}\text { Technical } \\
\text { lifetime }^{7}\end{array}$ \\
\hline \multicolumn{6}{|l|}{ Central BMVHR } \\
\hline system & 1.25 & 1.36 & 0.07 & $-0.45 h^{-1}$ & 40 years \\
\hline $\begin{array}{l}{ }^{1} \text { Wood-framed three } \\
{ }^{2} \text { Aluminum framed } \\
{ }^{3} \text { Technical lifetime of } \\
{ }^{4} \text { COP: Coefficient of } \\
{ }^{5} \text { Efficiency of heat pu } \\
\text { pump an average effic } \\
{ }^{6} \text { Technical lifetime of } \\
{ }^{7} \text { Technical lifetime of } \\
20 \text { years. With additio }\end{array}$ & $\begin{array}{l}\text { e windows (non-g } \\
\text { lows (gas filled), } \\
\text { pes and ventilatio } \\
\text { formance. } \\
\text { assumed to be } 4 \text {. } \\
\text { cy of } 3.0 \text {. } \\
\text { re hole is } 40 \text { year } \\
\text { cts, shafts and ap } \\
\text { maintenance, the }\end{array}$ & $\begin{array}{l}\text { s filled), } g \text {-value } 0 \\
\text { value } 0.43 \text {. } \\
\text { ducts is } 40 \text { years. } \\
\text { and covers } 90 \% \text { o } \\
\text { tment installation } \\
\text { partment installati }\end{array}$ & $\begin{array}{l}\text { space heating demand and } \\
\text { ed to be } 40 \text { years with nor }\end{array}$ & $\begin{array}{l}\text { of maximum power, } \\
\text { naintenance. Fan unit } \\
\text { and are replaced the }\end{array}$ & $\begin{array}{l}\text { iving the heat } \\
\text { replaced after }\end{array}$ \\
\hline
\end{tabular}

\subsubsection{Energy tariffs}

The energy prices used in the optimization are based on the local district heating company and include one part related to the maximum power demand (yearly fixed and dependent on maximal power) and one related to the energy use. The price varies depending on the time of year and also includes a water flow rate cost. In addition to district heating as a supply system, EEMs were identified with a ground source heat pump as the main heating system with the same energy saving targets. The electricity price is based on the local electricity grid and the fixed electricity price for one year from a local company. The costs are summarized in Table 4.

Table 4. Cost of district heating and electricity in Linköping, Sweden in 2019.

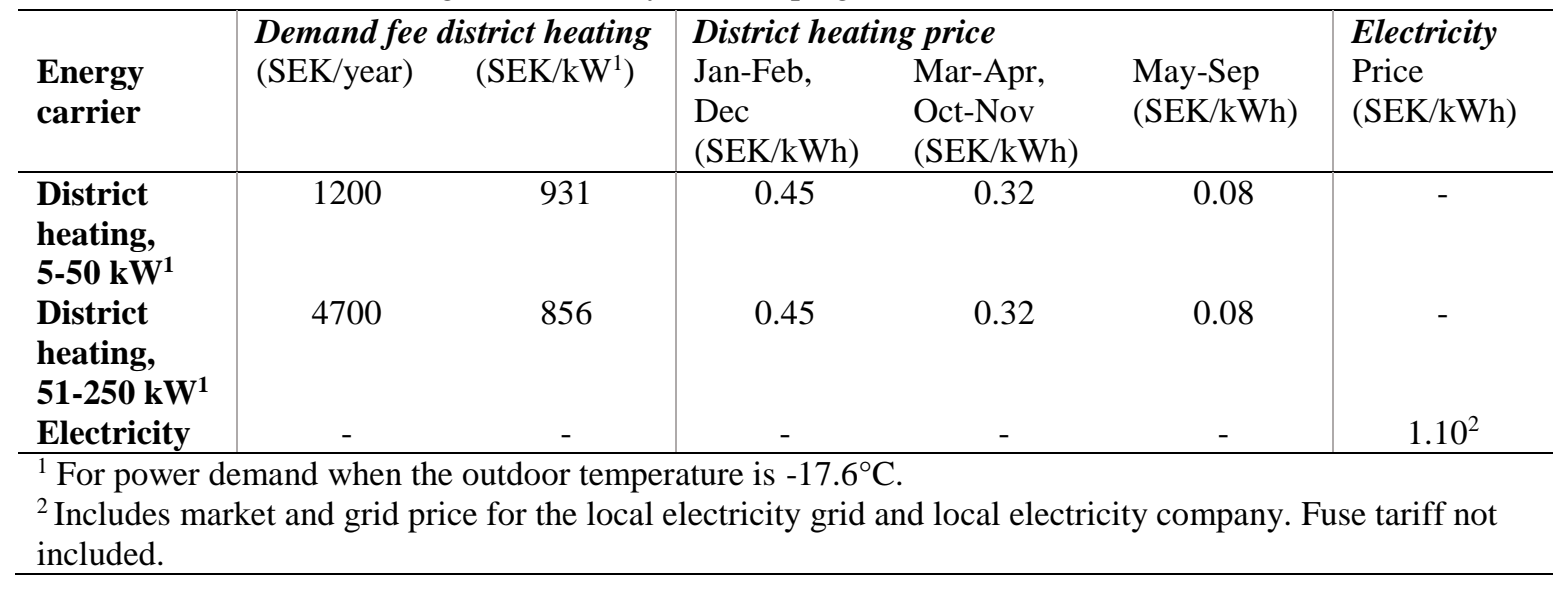

\subsubsection{Dynamic building energy simulations}

The validated IDA ICE model was used for a whole year simulation of space heating demand, with the EEMs identified with OPERA-MILP used as input data. Normal year 
corrected climate data from Linköping was used [48]. The IDA ICE model was slightly simplified so that the identified EEMs would be more easily implemented in the model and comparable to the heat balance. The simplifications included making ventilation airflows evenly distributed throughout the building, no time schedule for internal heat gains in the building, and thermal bridges representing $10 \%$ of the transmission losses in all simulations. The infiltration was simulated as wind driven.

\subsection{Sensitivity analysis}

In any calculation of costs during a building's life cycle, several aspects represent uncertainty factors. A sensitivity analysis has thus been performed to study how central factors affect the results. The sensitivity analysis includes variations in the thermal properties of the building envelope, district heating prices and operation costs for the ground source heat pump, annual increases in district heating prices, the cost of energy and energy efficiency measures, ventilation heat recovery efficiency, discount rate, and windows' solar heat gain factors. The sensitivity was tested in the LLCC case for all parameters except windows' solar heat gains factors, and the changes in parameters are summarized in Table 5. Only one parameter is changed in each sensitivity analysis; all other variables are constant from the LLCC case. The effect on space heating demand and indoor climate of different window solar heat gains factors, $g$-values, is studied by varying the $g$-value of the window with a $U$ value of $1.1 \mathrm{~W} / \mathrm{m}^{2 \circ} \mathrm{C}$ in a dynamic simulation with the performed renovation measures as input data. The space heating demand and hours with high indoor temperatures in the apartment with the highest solar exposure in the building are studied. 
Table 5. Parameters and range included in the sensitivity analysis.

\begin{tabular}{llll}
\hline Parameter & Existing value & Range & Step \\
\hline$U$-value of attic & $0.27 \mathrm{~W} / \mathrm{m}^{2} \cdot \mathrm{K}$ & $0.3-1.0$ & 0.05 \\
$U$-value of façade & $0.45 \mathrm{~W} / \mathrm{m}^{2} \cdot \mathrm{K}$ & $0.5-2.0$ & 0.1 \\
District heating price & $100 \% \mathrm{of} \mathrm{current} \mathrm{price}$ & $60-100 \%$ & $5 \%$ \\
Annual increase in district heating costs & $0 \%$ & $0.5-2 \%$ & $0.5 \%$ \\
Operation cost of heat pump & $100 \%$ of current cost & $50-160 \%$ & $10 \%$ \\
Ventilation heat recovery efficiency & $57.4 \%$ & $60-100 \%$ & $10 \%$ \\
Window $g$-value & 0.43 & $0.2-0.8$ & 0.2 \\
Discount rate & $5 \%$ & $1-10 \%$ & $1 \%$ \\
Cost of EEMs & $100 \%$ of current cost & $50-90 \%$ & $10 \%$ \\
\hline
\end{tabular}

\section{Results and discussion}

\subsection{Validation of quasi-steady state heat balance with IDA-ICE}

Since operation costs constitute an important part of the LCC of a building, it is essential that the heat balance calculation has a high degree of accuracy. IDA ICE version 4.8 has been used to validate the space heating demand from the quasi-steady state heat balance calculation used in OPERA-MILP. The monthly space heating demand in the reference case before renovation and after the performed renovation is seen in Figure 6. On a yearly basis, the dynamic simulation gives a space heating demand that is $1.3 \%$ lower than the calculation for the unrenovated building and 5.2\% higher for the renovated case. 

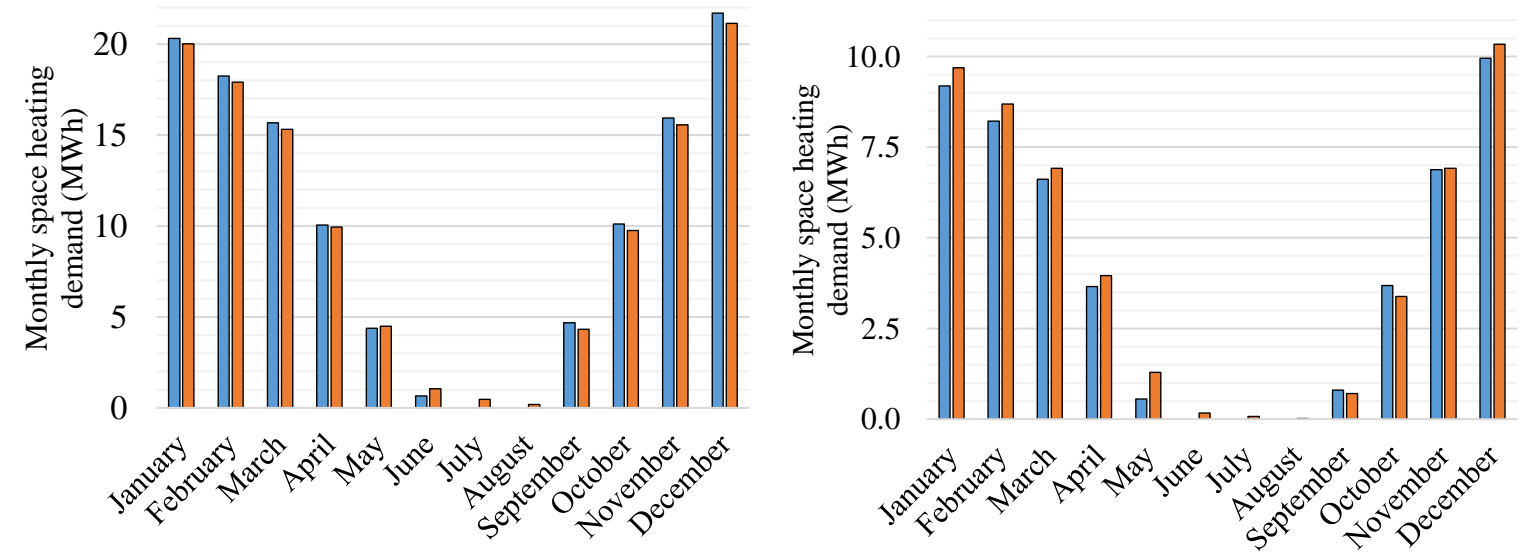

Figure 6. Monthly space heating demand from OPERA-MILP and IDA ICE for the building in the reference case (left) and performed renovation (right).

Due to the monthly time step in OPERA-MILP, internal heat gains are slightly overestimated which means that OPERA-MILP yields a lower space heating demand than the IDA-ICE dynamic simulation when the heat losses are smaller. This is especially clear in months with a significant amount of solar radiation and no or little space heating demand during the day, but relatively low temperatures with space heating demand at night, such as April. This means that some of the solar radiation is assumed to replace active heating when in reality there is no heat demand, due to the mismatch between the space heating demand and the availability of solar radiation. Solar heat gains are a problematic aspect of any static approach to energy calculation because of the inertia of buildings. However, using a dynamic simulation approach a relatively accurate estimate of the solar gain can be achieved. When buildings are ambitiously renovated so that heat losses are significantly reduced, the problem of solar radiation becomes even greater in a heat balance calculation, since the time of year when the building needs space heating during the day is reduced and the balance temperature to which active heating is required will be lower than the outdoor temperature for a large part 
of the year. A possible solution to this is to divide months into average temperatures and internal heat gains during the day and at night.

The heat losses due to transmission and ventilation in the quasi-steady state heat balance and the dynamic simulation of the reference case and the performed renovation can be seen in Figure 7. When comparing the heat losses from the OPERA-MILP calculation and the IDA-ICE simulation, the dynamic simulation has $0.5 \%$ higher losses than in the OPERAMILP heat balance calculation for the unrenovated case, and $8.8 \%$ higher in the renovated case.

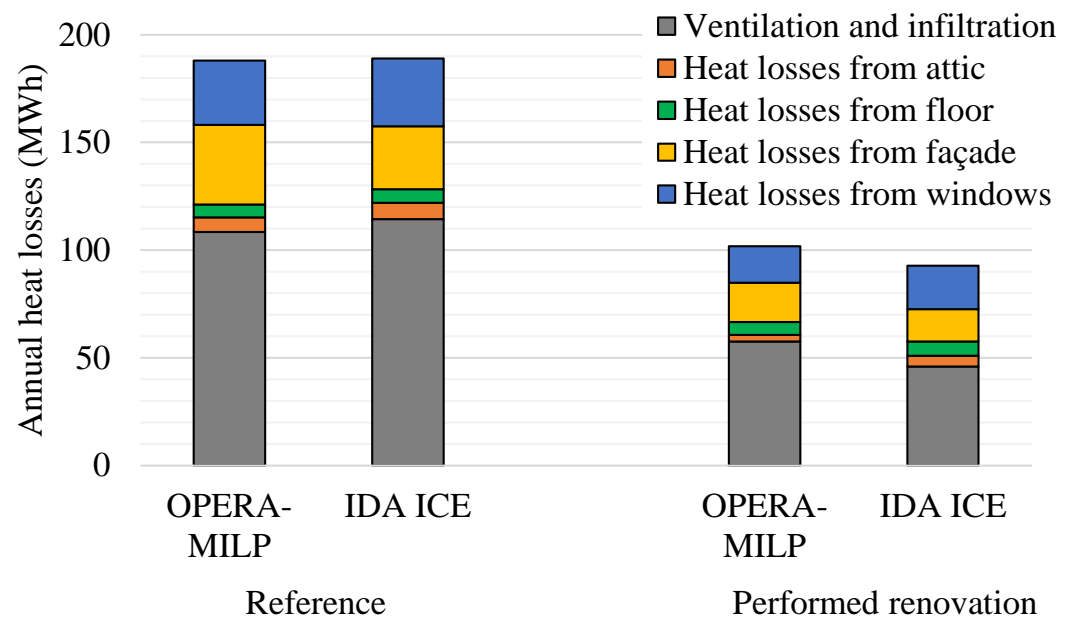

Figure 7. Heat losses from degree hour heat balance calculation in OPERA-MILP and dynamic simulation in IDA ICE.

\subsection{Optimal energy efficiency measures with district heating as the energy supply} system

If all EEMs included in the analysis are implemented, the heat balance calculation applied in OPERA-MILP gives an annual space heating demand of $34.2 \mathrm{MWh}$ $\left(31.9 \mathrm{kWh} / \mathrm{m}^{2} \cdot\right.$ year$)$, which is a reduction in space heating demand of $71.9 \%$ and hence serves as the upper limit of a possible energy saving target. 
The reference LCC for maintaining the building in its original form without any improvements to the thermal properties is 3.02 MSEK with district heating as the energy supply system. No energy saving measures are found to be optimal from a cost perspective when achieving the lowest LCC is the objective function. Note that all windows are replaced with new aluminum framed windows with a $U$-value of $1.1 \mathrm{~W} / \mathrm{m}^{2} \cdot \mathrm{K}$ since the existing windows have reached the end of their technical lifetime and need to be replaced. This yields a reduction in space heating demand of $3.5 \%$ and reduces the LCC by $0.17 \mathrm{MSEK}$. The marginal energy saving from window replacement can be explained by the lower g-value of the new windows, which means that the windows yield lower internal heat gains compared to the reference case. All measures that are optimal for each energy saving target are summarized in Table 6. Combinations of measures marked with "optimal" are identified using OPERA-MILP. Other combinations are not cost optimal. For example, with an energy saving target of $50 \%$ it is more cost-effective to reduce space heating demand by $59 \%$, and the cost of reducing space heating demand by $50 \%$ has been calculated to illustrate the cost.

\begin{tabular}{|c|c|c|c|c|c|c|c|c|c|c|c|c|}
\hline & \multicolumn{4}{|c|}{ Window $U$-value $\left(\mathbf{W} / \mathbf{m}^{2} \cdot \mathbf{K}\right)$} & \multicolumn{2}{|c|}{$\begin{array}{c}\text { Additional } \\
\text { insulation (m) }\end{array}$} & \multirow[b]{2}{*}{ BMVHR } & \multirow{2}{*}{$\begin{array}{c}\text { Space } \\
\text { heating } \\
\text { demand } \\
\left(\mathrm{kWh} / \mathrm{m}^{2} \cdot \mathrm{y}\right)\end{array}$} & \multirow{2}{*}{$\begin{array}{c}\text { Power } \\
\text { demand } \\
(\mathbf{k W})\end{array}$} & \multirow{2}{*}{$\begin{array}{c}\text { Reduced } \\
\text { space heating } \\
\text { demand }\end{array}$} & \multirow[b]{2}{*}{$\begin{array}{c}\text { LCC } \\
(\text { MSEK) }\end{array}$} & \multirow[b]{2}{*}{ Optimal $^{1}$} \\
\hline & North & East & South & West & Façade & Attic & & & & & & \\
\hline Reference & 1.9 & 1.9 & 1.9 & 1.9 & - & - & - & 113.5 & 57.40 & & 3.02 & No \\
\hline LLCC & 1.1 & 1.1 & 1.1 & 1.1 & - & - & - & 109.5 & 53.57 & $-3.5 \%$ & 2.85 & Yes \\
\hline$-10 \%$ & 0.8 & 1.1 & 0.8 & 1.1 & - & 0.30 & - & 102.1 & 51.01 & $-10.0 \%$ & 2.93 & Yes \\
\hline$-20 \%$ & 1.1 & 1.1 & 1.1 & 1.1 & 0.12 & - & - & 90.2 & 46.89 & $-20.5 \%$ & 3.46 & Yes \\
\hline$-30 \%$ & 1.1 & 0.8 & 0.8 & 0.8 & 0.22 & 0.36 & - & 79.4 & 43.13 & $-30.0 \%$ & 3.55 & Yes \\
\hline$-40 \%$ & 1.1 & 1.1 & 1.1 & 1.1 & - & - & Yes & 65.2 & 38.06 & $-42.5 \%$ & 3.65 & Yes \\
\hline$-50 \%$ & 1.1 & 1.1 & 1.1 & 1.1 & 0.03 & - & Yes & 56.7 & 34.98 & $-50.0 \%$ & 4.31 & No \\
\hline$-59 \%$ & 1.1 & 1.1 & 1.1 & 1.1 & 0.12 & - & Yes & 46.8 & 31.37 & $-58.8 \%$ & 4.26 & Yes \\
\hline$-60 \%$ & 1.1 & 1.1 & 1.1 & 1.1 & 0.16 & - & Yes & 44.7 & 30.61 & $-60.7 \%$ & 4.26 & Yes \\
\hline$-70 \%$ & 0.8 & 0.8 & 0.8 & 0.8 & 0.26 & 0.36 & Yes & 34.0 & 26.64 & $-70.0 \%$ & 4.39 & Yes \\
\hline Max. & 0.8 & 0.8 & 0.8 & 0.8 & 0.40 & 0.40 & Yes & 31.9 & 25.75 & $-71.9 \%$ & 4.48 & No \\
\hline
\end{tabular}


${ }^{1}$ Combination of energy efficiency measures marked as optimal have been identified using OPERA-MILP.

Table 6. EEMs, energy use, maximum power demand, reduction in space heating demand and total LCC for the different renovation packages and maintenance in original building.

Insulating the façade has a higher potential for increasing energy efficiency because it has a higher $U$-value than the attic prior to renovation, but the cost is higher compared to attic insulation and the area is larger Although the potential to reduce space heating demand is higher for the walls, attic insulation is the first insulation measure that is found to be costeffective when moving beyond the LLCC. However, the limited area and relatively good thermal performance prior to renovation means a limited energy efficiency potential, and façade insulation has to be applied to achieve higher energy saving targets. A BMVHR system is the optimal solution when an energy saving target of $40 \%$ is the objective function. The non-linearity of the installation cost of the BMVHR system and a large reduction in heat losses means that the actual reduction in space heating demand is slightly higher than the target, even though no other EEMs are included. It is not possible to achieve a reduction in space heating demand of $40 \%$ by only improving the building envelope. The maximal reduction achieved by thermal improvements of façade, attic and windows included in the analysis is $33.2 \%$ at an LCC of 3.47 MSEK.

The LCC and space heating demand for the different energy saving targets are visualized in Figure 8. The performed renovation achieves a theoretical reduction in space heating demand of $59.3 \%$ using the quasi-steady state heat balance calculation. The performed renovation has a slightly higher LCC than the cost-optimal level. An optimization with the same energy saving target as the actual energy renovation shows that it would be 
more cost-effective to add $0.16 \mathrm{~m}$ of additional external wall insulation and not to add any additional insulation to the attic. This gives a space heating demand of $45.6 \mathrm{kWh} / \mathrm{m}^{2} \cdot$ year at an LCC of 4.26 MSEK. Figure 8 also indicates the importance of analyzing the selected renovation approach in relation to other options. The measures found to be optimal with an energy saving target between $20 \%$ and $40 \%$ have similar LCCs, but vary greatly in terms of space heating demand. The figure also shows the cost if additional maintenance (replacing apartment installations after 20 years) is performed.

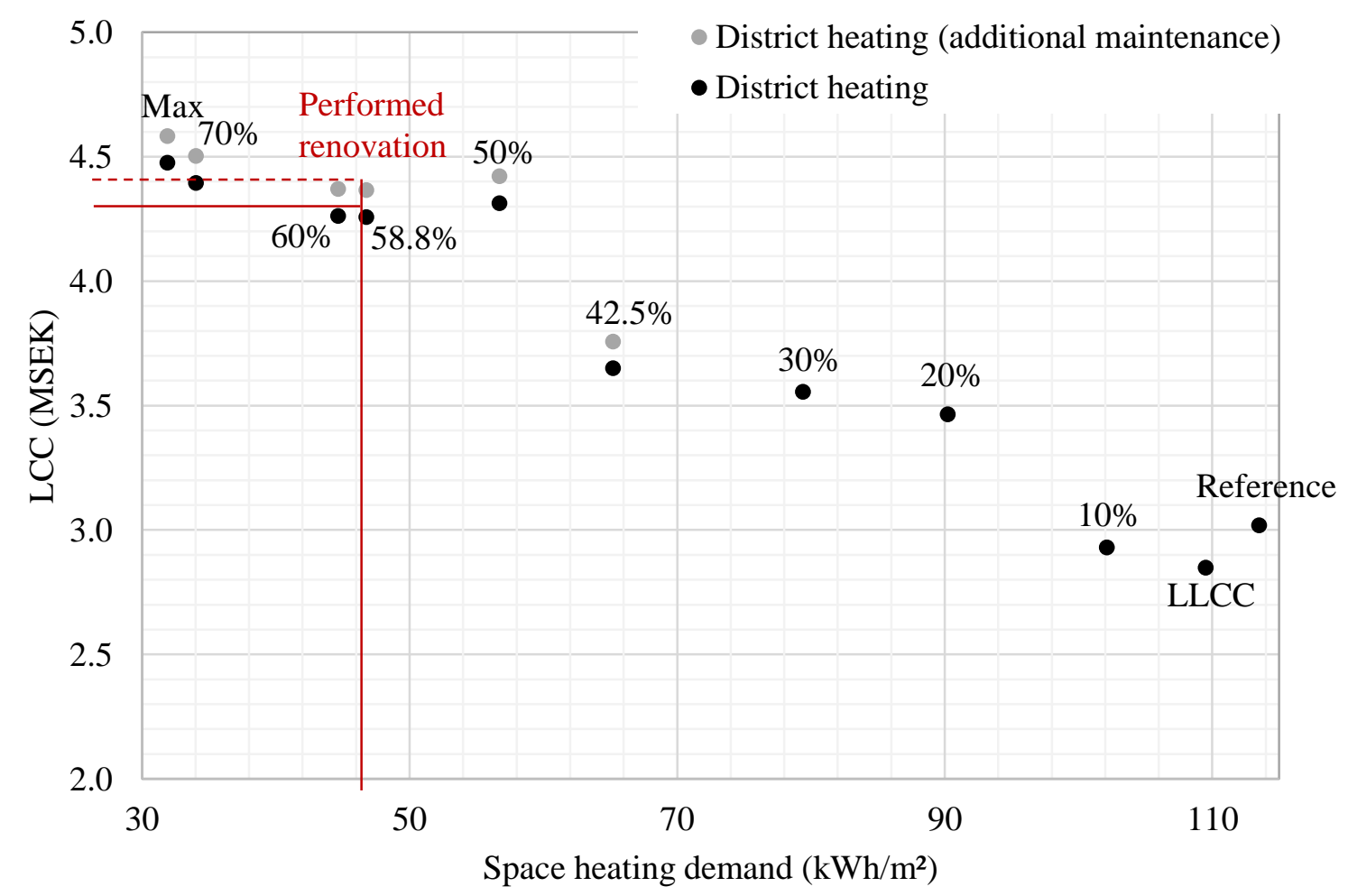

Figure 8. LCC and space heating demand for the different energy saving targets, original building, actual renovation and maximum. The dotted line represents the cost of the performed renovation with additional maintenance of the BMVHR system.

How the cost is divided up between different building components and investments can be seen in Figure 9. The inevitable maintenance costs represent a large part of the total LCC, especially when no or moderate energy saving targets are set. The inevitable cost is slightly higher for the reference building since the wood frame windows have a shorter life cycle than 
the windows with aluminum frames. Façade insulation and BMVHR system installation are expensive investments compared to attic insulation and investment in better windows than the standard windows with a $U$-value of $1.1 \mathrm{~W} / \mathrm{m}^{2} \cdot \mathrm{K}$. The largest proportion of the operation costs relates to the power demand fee for the district heating tariff in Linköping, Sweden.

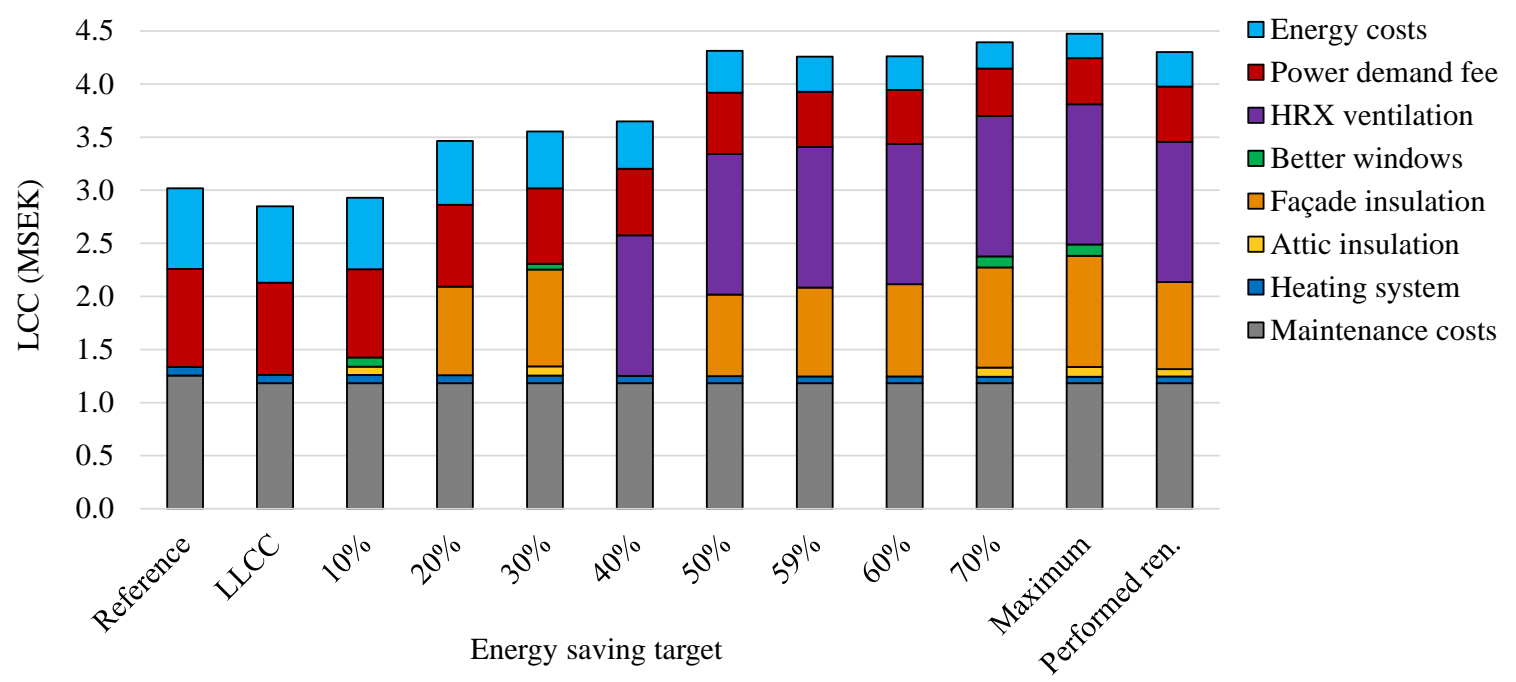

Figure 9. LCC costs divided up into costs for operation, maintenance and EEMs.

The LCC includes costs that occur at the time of renovation and in future investment and operation. With an ambitious energy saving target, a larger investment is needed at the present time, see Figure 10. If a BMVHR system is installed, future investments are also needed to replace the fan. A less ambitious energy saving target requires less investment at the present time, but has a high cost for operation of the building. An energy saving target between $20 \%$ and $40 \%$ has a similar total LCC, but varies when the investment is needed at the time of renovation. 


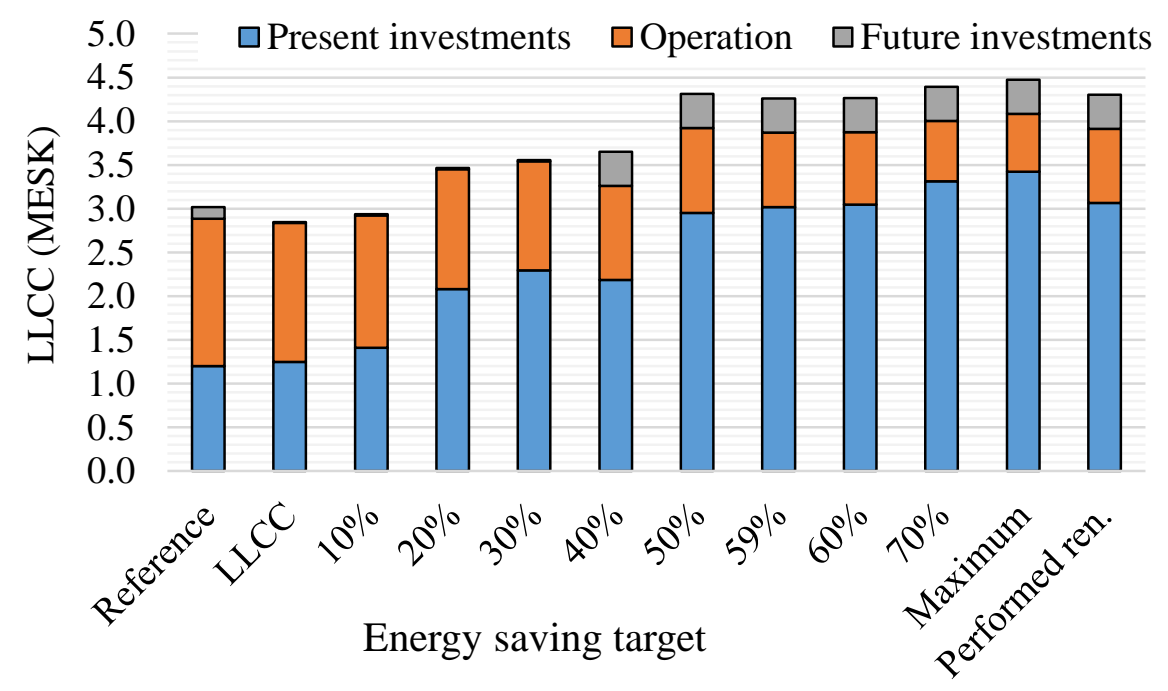

Figure 10. Cost of investment at the present time, discounted future investment and operation costs.

Figure 11 shows how the LCC per $\mathrm{kWh}$ of space heating demand increases more vigorously beyond an energy saving target of $40 \%$, while the reduction in the specific space heating demand is less vigorous. It is worth mentioning that significant investment is needed to achieve an energy performance for a renovated building comparable to a new building constructed in accordance with national building performance requirements [49]. The maximal allowed primary energy use for a newly constructed multifamily building heated with district heating in central Sweden is $85 \mathrm{kWh} / \mathrm{m}^{2}$.year, including domestic hot water and facility electricity. 


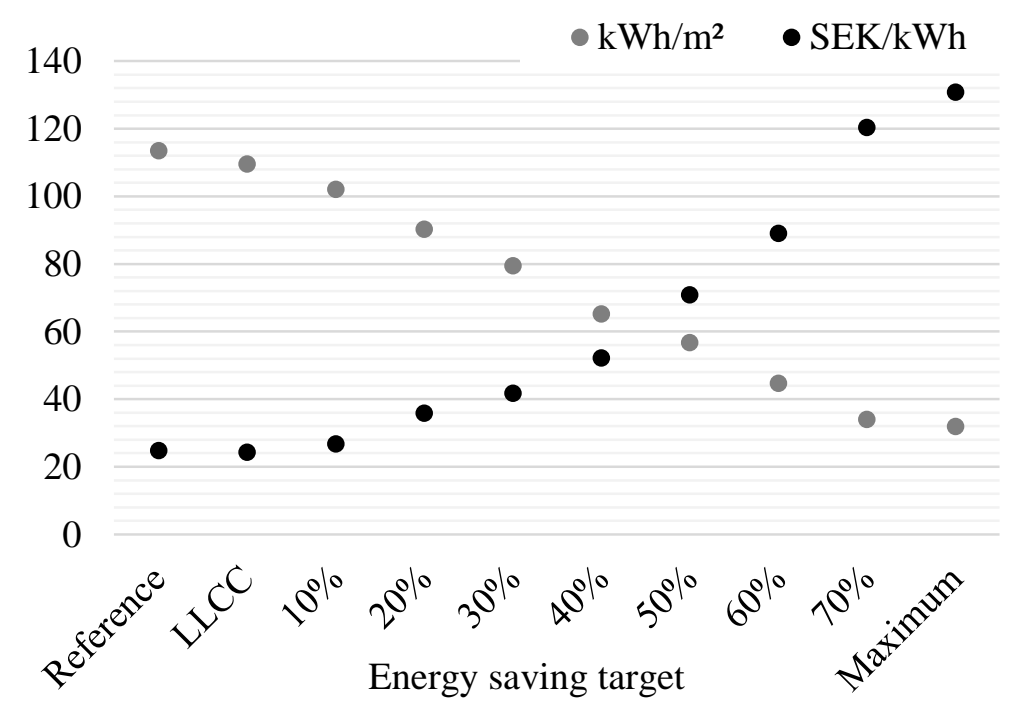

Figure 11. Total LCC per kWh of space heating demand (black) and space heating demand per heated area (gray).

OPERA-MILP identifies the combination of EEMs that has the lowest LCC. However, as can be seen in Figure 12, some energy saving targets require a much higher increase in LCC per reduced $\mathrm{kWh}$ of space heating demand. The largest increase in LCC occurs when façade insulation is applied in the $20 \%$ energy saving target. Attic insulation (target 10\%) and BMVHR system installation (target 40\%) increase the LCC less per reduction in space heating demand than other combinations of EEMs. The 10\% and 40\% energy saving targets are the only combinations that do not include façade insulation, indicating that façade insulation requires a larger investment per reduction of space heat demand compared to other EEMs. 


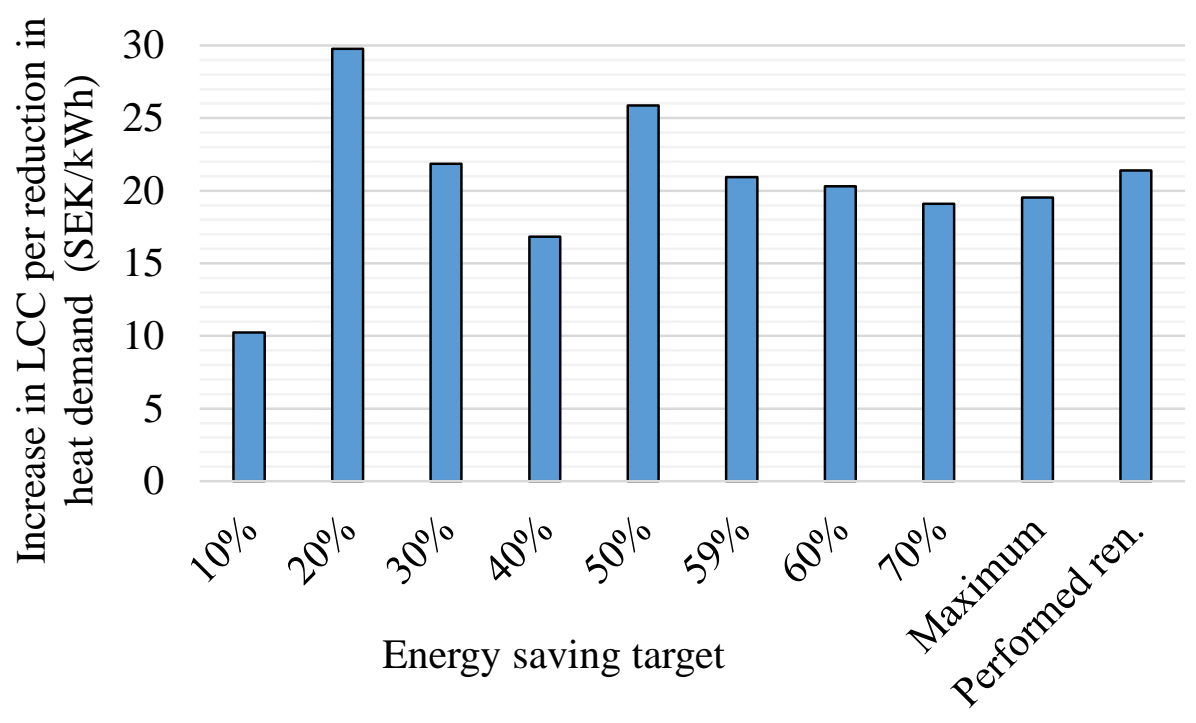

Figure 12. Increase in LCC per reduced space heating demand in each energy saving target.

\subsection{Validation of optimized renovations}

The difference between annual space heating demand from the heat balance calculation in OPERA-MILP and the dynamic simulation in IDA ICE for all renovation packages is seen in Figure 13. The difference is $7 \%$ or lower up to a $70 \%$ energy saving target, which means that the quasi-steady state heat balance approach gives a reasonable level of accuracy. When the building has small heat losses, the solar heat gain estimate from simulations and the internal heat gains from appliances make up a large proportion of the space heating demand, and hence slightly overestimate the potential from the EEMs. 


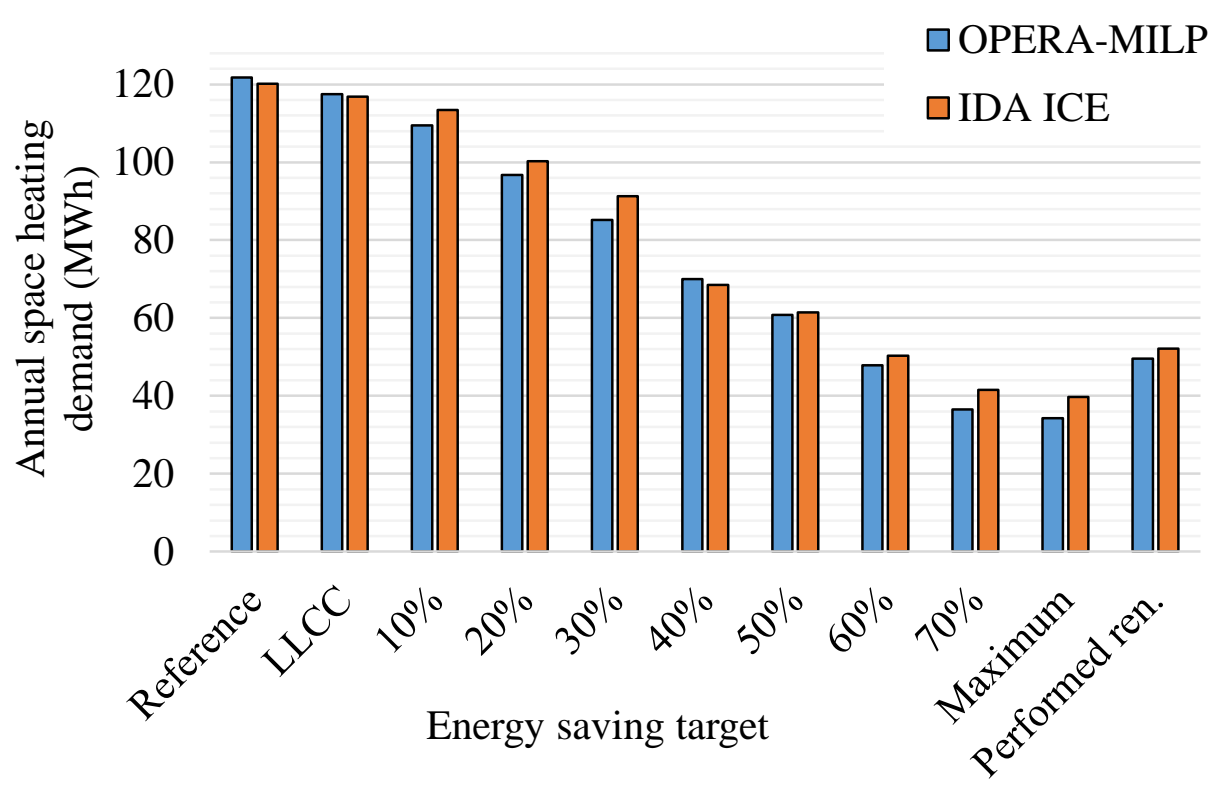

Figure 13. Annual space heating demand from degree hour heat balance (OPERA-MILP) and dynamic simulation (IDA ICE) for all energy saving targets. The difference in the calculated space heating demand in OPERA-MILP compared to the dynamic simulation is seen above the bars.

\subsection{Comparison between district heating and heat pump as supply energy systems}

Many of the district heating systems in Sweden are relatively resource efficient, and use biofuels or low-grade fuels such as household waste [50]. Excess heat from industrial processes and combined heat and power generation is also common in Swedish district heating systems. From a cost perspective, other alternative energy supply systems can be cost-effective. Ground source heat pumps have become common in Sweden [51]. The results show that a ground source heat pump would be a slightly more cost-effective alternative compared with district heating, see Figure 14, with an average COP of the ground source heat pump above 3. The LCC optimal level of EEMs is slightly higher when the COP of the heat pump is 2 compared to a higher COP, since the operation costs are higher (energy saving target $20 \%$ and $50 \%$ ). 


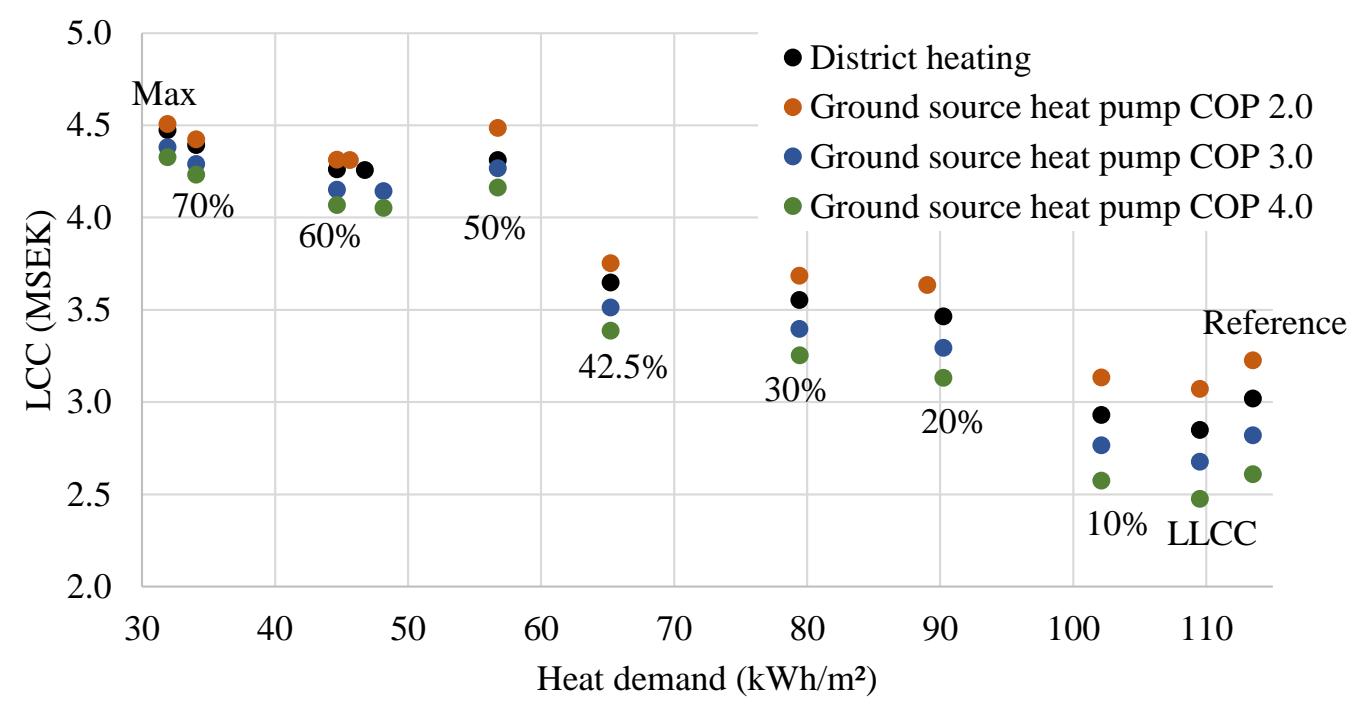

Figure 14. LCC for the building heated with district heating and ground source heat pump at different energy saving targets.

\subsection{Sensitivity analysis}

The existing thermal properties of the building envelope determine to a large degree whether insulation measures are cost optimal. The poorer the quality, the more likely it is that insulation will be part of the LLCC for a building. In the current case, insulation of the attic and façade becomes part of the LLCC when the $U$-values of the existing building before renovation are $0.5 \mathrm{~W} / \mathrm{m}^{2} \cdot \mathrm{K}$ and $1.3 \mathrm{~W} / \mathrm{m}^{2} \cdot \mathrm{K}$ respectively (no other variables are changed in the optimizations), see Figure 15. With current energy prices, a building has to have a very poor thermal performance for insulation measures to be cost-effective. 


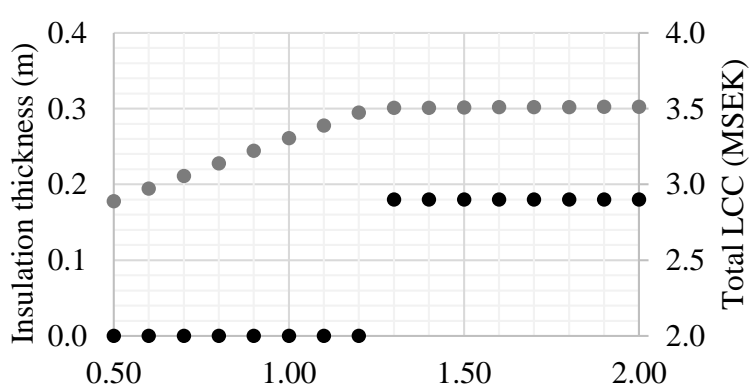

$\mathrm{U}$-value of the existing facade before renovation

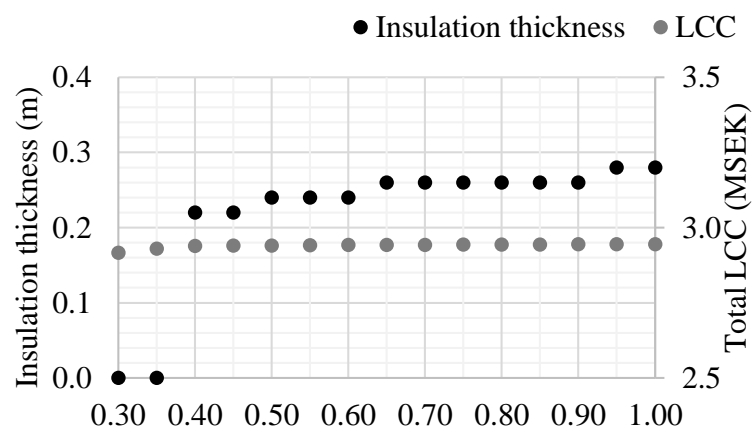

U-value of the existing attic before renovation

Figure 15. LCC and additional insulation thickness in the LLCC case for different $U$-values of the attic (left) and façade (right).

The sensitivity analysis includes two aspects that affect the optimal heating system in the LLCC case: the price of district heating and the cost of operation for the ground source heat pump, see Figure 16. As explained in Section 3.1, OPERA-MILP can suggest a combination of a heat pumps and district heating as a heat supply system. If the operation cost for district heating depends on the installed capacity of the heat exchanger and varies during the season, a combination of a heat pump and district heating can be cost-effective. With the current price of district heating and electricity, a ground source heat pump with an average COP of 3 is more cost-effective. When the price of district heating is lowered to $90 \%$ of current costs, district heating will be the cost optimal solution. The operation cost of the ground source heat pump can be affected by either the electricity cost or the COP. When the operation cost increases to $160 \%$ of the current operation cost, district heating is the optimal and most cost-effective energy supply system. 

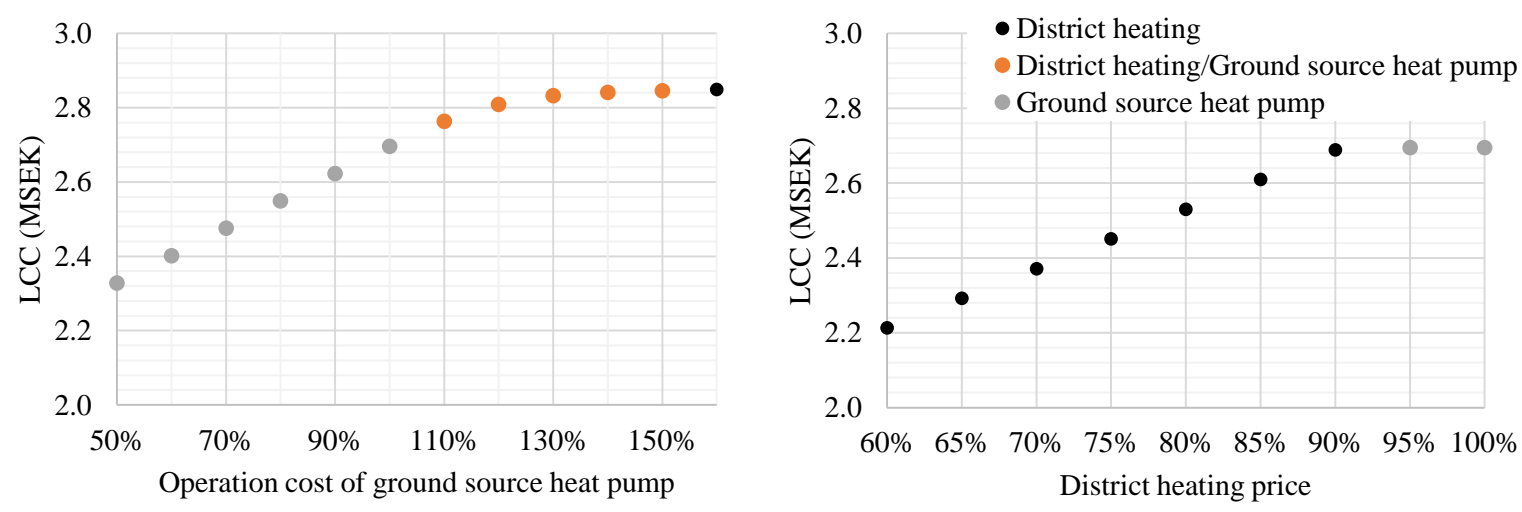

Figure 16. LCC and optimal heating system for different operation costs of the ground source heat pump (left) and district heating costs (right).

The maximum power of the district heating exchanger is $53.6 \mathrm{~kW}$ in the LLCC case. Since the district heating tariff in Linköping is lower for a maximum power demand below $50 \mathrm{~kW}$ (see Table 4), OPERA-MILP finds a combination of district heating and a ground source heat pump when the operation cost for the heat pump is between $110 \%$ and $150 \%$ of current operation costs. The district heating tariff in Linköping also has lower costs during the spring, summer and autumn. When the operation cost of the ground source heat pump is increased, the installed power of the ground source heat pump is reduced and a district heating exchanger is installed and used to supply energy during the low cost periods. Figure 17 shows the installed power of the energy supply system and Figure 18 shows the energy supplied from district heating and the ground source heat pump. The heat pump is primarily used when the district heating is more expensive, during December, January and February. The COP of the heat pump is assumed to be constant since it uses ground source heat and DHW is excluded from heat demand. Note that if DHW is also considered, the maximal power demand as well as the COP will be affected. 


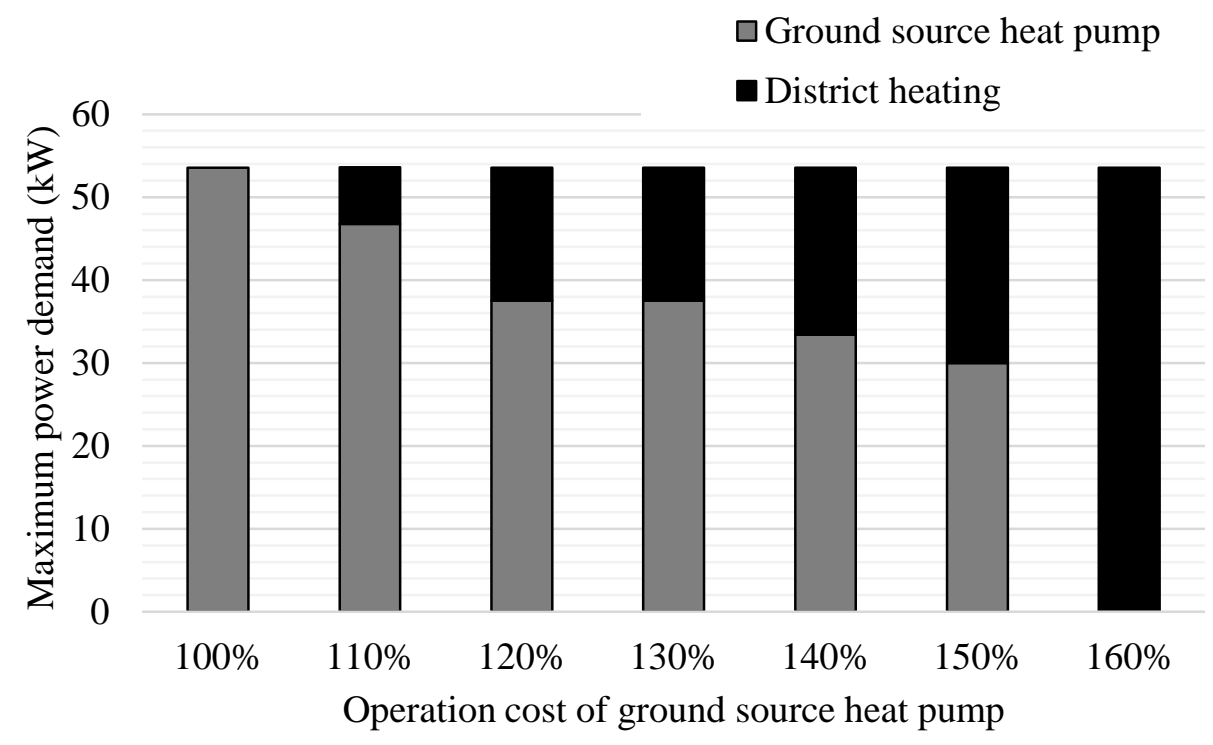

Figure 17. Maximum power of ground source heat pump and district heating with different operation costs for ground source heat pump.

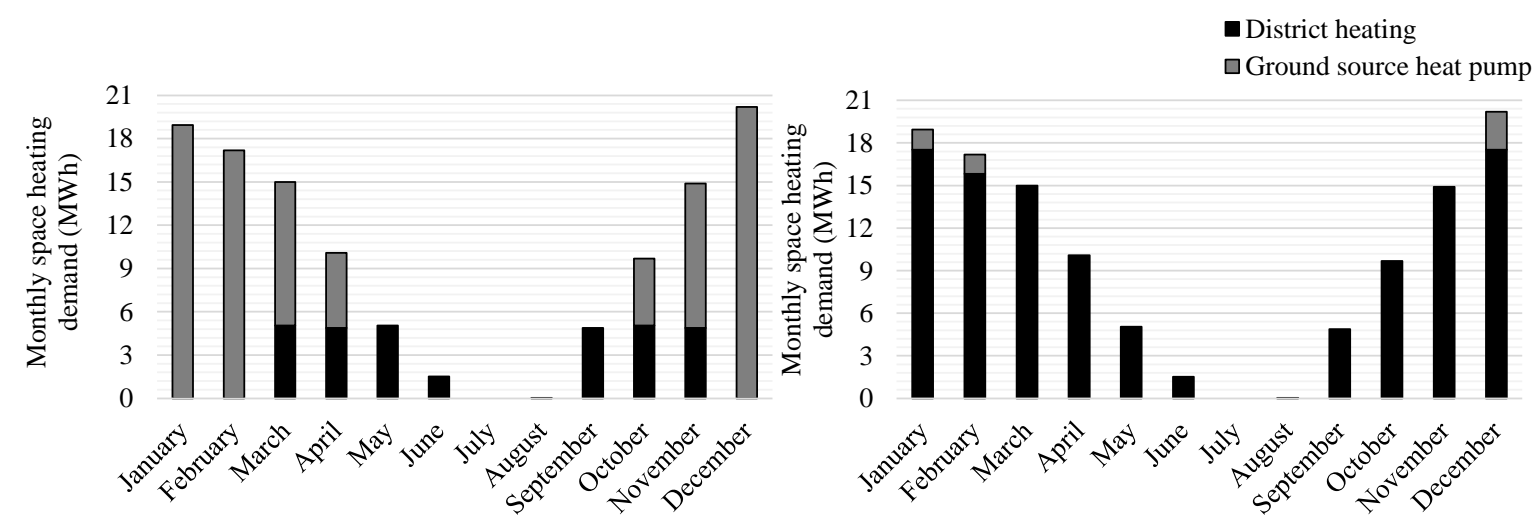

Figure 18. Space heating demand and energy supply system with $110 \%$ (left) and $150 \%$ (right) operation cost of the ground source heat pump.

During the last five years the annual change in the real district heating price has ranged between $-3.8 \%$ and $2.1 \%$, averaging at an increase of $0.3 \%$ [52]. The increase in energy price has thus been marginal for district heated buildings in Sweden. The effect from an annual and constant increase in district heating costs has been studied using an adjusted real interest rate. The analysis shows that no EEMs are cost effective to achieve the LLCC even at a constant increase in district heating costs of $2 \%$. The increase in LCC can be seen in Figure 19. 


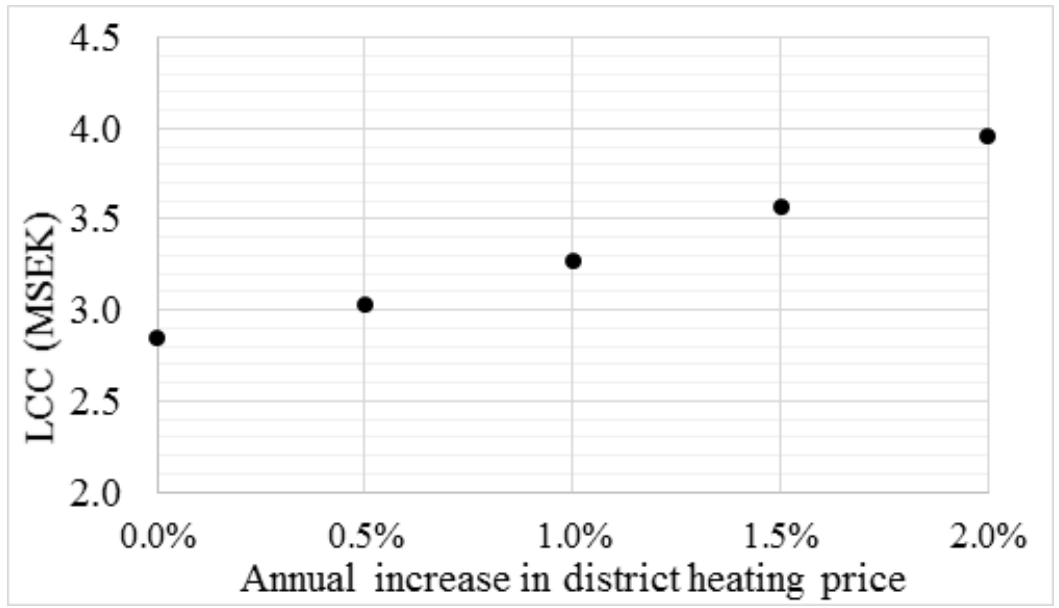

Figure 19. LCC at an annual increase in district heating price between $0 \%$ and $2 \%$.

The sensitivity analysis shows that a BMVHR system with higher heat recovery efficiency than $57.4 \%$ does not make a difference in the LLCC case. Even at a theoretical heat recovery efficiency of $100 \%$, where no heat losses would occur from ventilation, it is not a cost optimal EEM for achieving the LLCC. The cost of investing in a BMVHR system is too large in relation to the cost saving from reduced space heating demand at current district heating costs for it to achieve the LLCC. The cost of the EEMs is of course an important aspect of the cost effectiveness of energy renovations. When the costs of all EEMs are reduced to $50 \%$ of current costs, $0.28 \mathrm{~m}$ attic insulation is suggested as an EEM when the LLCC is the objective function. The LCC is then reduced by 0.01 MSEK compared to the original LLCC. The heat demand is reduced from 109.5 to $105.6 \mathrm{kWh} / \mathrm{m}^{2}$.

The windows included in the analysis have a $g$-value of 0.43 and a $U$-value of 1.1 $\mathrm{W} / \mathrm{m}^{2} \cdot \mathrm{K}$. A higher $g$-value means higher solar heat gains and lower space heating demand. On the other hand, high solar heat gains mean problems with high indoor temperatures during the summer, especially in buildings with good thermal performance. Although the space heating demand and LCC are reduced, a dynamic simulation of the building after the performed renovation indicates that problems with temperatures above $26^{\circ} \mathrm{C}$ increase 
drastically in the most solar exposed apartment in the building when the $g$-value is higher than the windows installed in the performed renovation, see Figure 20. No solar shading was used in the simulations. Solar shading, for example external awnings, would reduce the problem of high indoor temperatures. The window $g$-value can also have an effect on the demand for artificial lighting and should be considered in relation to the space heating demand and indoor climate.

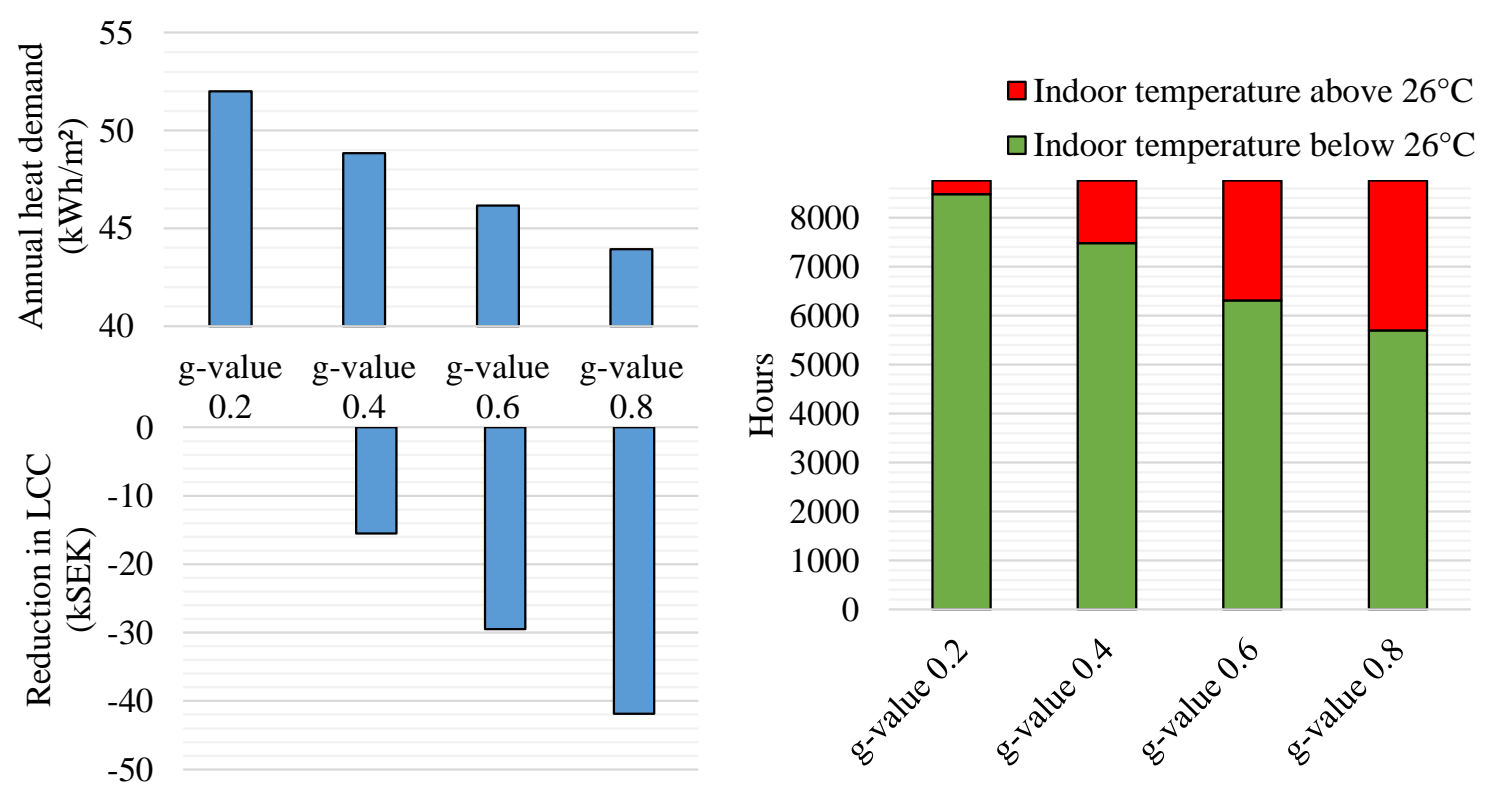

Figure 20. Annual space heating demand, reduction in LCC and hours with indoor temperatures above $26^{\circ} \mathrm{C}$ with different windows' $g$-values in the LLCC case in the most solar exposed apartment.

The discount rate was assumed to be $5 \%$ in the optimizations performed in the analyses and the presented LCCs. A lower discount rate means that the LCC increases, see Figure 21. No further EEMs are found to be cost optimal and part of the LLCC until a real interest rate of $1 \%$ is set. Insulation of the attic is then cost-effective. 


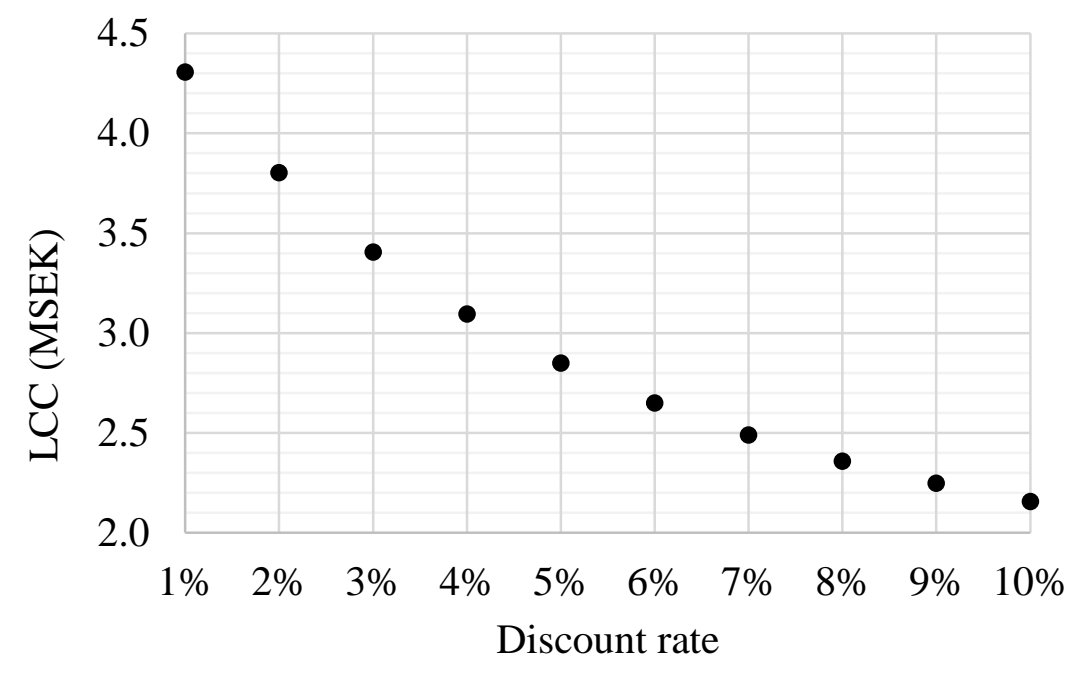

Figure 21. LCC at different discount rates for the LLCC case.

\section{Concluding discussion}

This study offers an optimization approach to studying building energy renovation and shows which combination of energy efficiency measures (EEMs) is most cost-effective with different energy saving targets for an energy renovation of a multifamily building in Sweden. The study uses the optimization tool OPERA-MILP, which is a tool for minimizing the life cycle cost (LCC) during a selected life cycle of a building. The quasi-steady state heat balance calculation in the OPERA-MILP method was supported by dynamic simulation of solar heat gains, and the results show a good agreement with a dynamic simulation of the annual and monthly space heating demand.

The study shows that it is not cost-effective from an LCC perspective to invest in ambitious EEMs to reduce space heating demand. The studied building was in need of major renovation and the building envelope, including windows, was in need of maintenance or replacement. The lowest LCC is achieved when modern windows with a $U$-value of $1.1 \mathrm{~W} / \mathrm{m}^{2} \cdot \mathrm{K}$ and a longer technical lifetime than the original window type are installed and 
no other EEMs are implemented. It should be noted that although no EEMs are found cost effective to achieve the lowest LCC, the thermal comfort is generally better in a building that has undergone an ambitious energy renovation than in a building with poor thermal performance.

The costs for the supply energy represent a relatively small part of the LCC and cannot compensate for the large capital investment needed to reduce heat losses. Low energy price thus act as a barrier for the cost effectiveness of energy renovation as well as energy efficiency improvement and reduced greenhouse gas emissions from the building stock. Measures on the ventilation system are often described as expensive, and in the studied building an energy saving target of more than $40 \%$ is needed for a BMVHR system to be cost-effective. Even if the heat recovery efficiency was $100 \%$ in the BMVHR system, it is not a cost-effective solution to implement when the lowest possible LCC is the target. Façade insulation has the highest increase in LCC per reduction of space heating demand and is the least cost-effective measure among the studied EEMs. It should be noted that the $U$-value of the façade was relatively low prior to energy renovation and a higher $U$-value would increase the cost-effectiveness of insulation of the façade. Still, there is significant potential for reducing heat losses from the external walls, which means that façade insulation is suggested as an EEM for achieving several of the energy saving targets. The analysis shows that the LCC of the performed energy renovation in the buildings was slightly higher than the costoptimal level and that it would have been more cost-effective to insulate the façade more and not add additional insulation to the attic to achieve the same energy saving and lower LCC. 
The optimal EEMs in an energy renovation will be dependent on the costs for implementing measures, which will vary between different building types. The results from this study are valid for similar buildings in similar climatic conditions, but still highlight the importance of a comprehensive approach to find the cost-optimal EEMs for the specific building. The study shows by using dynamic energy simulation that it is possible to use a simplified approach for prediction of heat demand with a quasi-steady state heat balance calculation and still achieve accurate results. The energy costs and energy supply system are also important. The studied building is located in and connected to the district heating network both before and after the energy renovation. The main competitor to district heating in Sweden is ground source heat pumps, which are shown to be more economically feasible than district heating. The current district heating price needs to be lowered by $10 \%$ to be the cost optimal solution in the LLCC case.

Several energy saving targets for the energy renovation were shown to have similar LCCs, although they varied greatly in space heating demand. Carefully considering the long life cycle of a building and the energy saving potential of different EEMs in relation to energy costs is therefore essential for cost-effective energy renovation of an aging building stock.

\section{Acknowledgements}

This study has been financed by the Swedish Research Council Formas.

\section{References}

[1] European Commission, Energy Performance of Buildings, (2018). https://ec.europa.eu/energy/en/topics/energy-efficiency/buildings.

[2] Swedish National Board of Housing Building and Planning, Bättre koll på underhåll, Boverket, Karlskrona, Sweden., 2003. https://www.boverket.se/sv/om- 
boverket/publicerat-av-boverket/publikationer/2003/battre-koll-pa-underhall-/.

[3] Swedish National Board of Housing Building and Planning, Underlag till den andra nationella strategin för energieffektiviserande renovering, Boverket, Karlskrona, Sweden., 2016. https://www.boverket.se/sv/om-boverket/publicerat-avboverket/publikationer/2016/underlag-till-den-andra-nationella-strategin-forenergieffektiviserande-renovering/.

[4] European Parliament, Directive 2018/844 of the European Parliament and of the Council - amending Directive 2010/31/EU on the energy performance of buildings and Directive 2012/27/EU on energy efficiency, 2018. doi:10.1007/3-540-478914_10.

[5] P. Gluch, H. Baumann, The life cycle costing (LCC) approach: A conceptual discussion of its usefulness for environmental decision-making, Building and Environment. 39 (2004) 571-580. doi:10.1016/j.buildenv.2003.10.008.

[6] L. Liu, P. Rohdin, B. Moshfegh, LCC assessments and environmental impacts on the energy renovation of a multi-family building from the 1890s, Energy and Buildings. 133 (2016) 823-833. doi:10.1016/j.enbuild.2016.10.040.

[7] V. Milić, K. Ekelöw, B. Moshfegh, On the performance of LCC optimization software OPERA-MILP by comparison with building energy simulation software IDA ICE, Building and Environment. (2017). doi:10.1016/j.buildenv.2017.11.012.

[8] M. Spickova, R. Myskova, Costs Efficiency Evaluation using Life Cycle Costing as Strategic Method, Procedia Economics and Finance. 34 (2015) 337-343. doi:10.1016/S2212-5671(15)01638-X.

[9] N.W.O. Brown, T. Malmqvist, W. Bai, M. Molinari, Sustainability assessment of renovation packages for increased energy efficiency for multi-family buildings in Sweden, Building and Environment. $61 \quad$ (2013) 140-148. doi:10.1016/j.buildenv.2012.11.019.

[10] M. Almeida, M. Ferreira, Cost effective energy and carbon emissions optimization in building renovation (Annex 56), Energy and Buildings. 152 (2017) 718-738. doi:10.1016/j.enbuild.2017.07.050.

[11] T. Niemelä, R. Kosonen, J. Jokisalo, Cost-effectiveness of energy performance renovation measures in Finnish brick apartment buildings, Energy and Buildings. 137 (2017) 60-75. doi:10.1016/j.enbuild.2016.12.031.

[12] L. Liu, P. Rohdin, B. Moshfegh, Investigating cost-optimal refurbishment strategies for the medieval district of Visby in Sweden, Energy and Buildings. 158 (2018) 750760. doi:10.1016/J.ENBUILD.2017.10.002.

[13] M.S. Tokarik, R.C. Richman, Life cycle cost optimization of passive energy efficiency improvements in a Toronto house, Energy and Buildings. 118 (2016) 160-169. doi:10.1016/j.enbuild.2016.02.015.

[14] S.N. Murray, B.P. Walsh, D. Kelliher, D.T.J. O'Sullivan, Multi-variable optimization of thermal energy efficiency retrofitting of buildings using static modelling and genetic algorithms - A case study, Building and Environment. 75 (2014) 98-107. doi:10.1016/j.buildenv.2014.01.011.

[15] P. Gluch, M. Gustafsson, The acceptance and use of life cycle costing (LCC) as 
decision support tool for renovation investment, International Conference on Construction and Real Estate Management. (2015).

[16] T. Ekström, R. Bernardo, A. Blomsterberg, Cost-effective passive house renovation packages for Swedish single-family houses from the 1960s and 1970s, Energy and Buildings. 161 (2018) 89-102. doi:10.1016/j.enbuild.2017.12.018.

[17] K. Kuusk, T. Kalamees, M. Maivel, Cost effectiveness of energy performance improvements in Estonian brick apartment buildings, Energy and Buildings. 77 (2014) 313-322. doi:10.1016/j.enbuild.2014.03.026.

[18] J. Palm, K. Reindl, Understanding barriers to energy-efficiency renovations of multifamily dwellings, Energy Efficiency. 11 (2018). doi:10.1007/s12053-017-95499.

[19] K. Reindl, Implementing energy measures in renovations for multi-family dwellings : Influence and practice of professionals, Linköping Studies in Arts and Science Doctoral Thesis No. 720, Technology and Social Change, Department of Thematic Studies, Linköping University, 2017. doi:10.3384/diss.diva-139892.

[20] L. La Fleur, B. Moshfegh, P. Rohdin, Measured and predicted energy use and indoor climate before and after a major renovation of an apartment building in Sweden, Energy and Buildings. 146 (2017) 98-110. doi:10.1016/j.enbuild.2017.04.042.

[21] L. La Fleur, B. Moshfegh, P. Rohdin, Energy performance of a renovated multi-family building in Sweden, Mediterranean Green Buildings and Renewable Energy: Selected Papers from the World Renewable Energy Network's Med Green Forum. (2016). doi:10.1007/978-3-319-30746-6_39.

[22] L. La Fleur, P. Rohdin, B. Moshfegh, Energy Use and Perceived Indoor Environment in a Swedish Multifamily Building before and after Major Renovation, Sustainability 2018, Vol. 10, Page 766. 10 (2018) 766. doi:10.3390/SU10030766.

[23] International Standard ISO 6946:2007, Building components and building elements Thermal resistance and thermal transmittance - Calculation method, (2007).

[24] International Standard ISO 13370:2007, Thermal performance of buildings - Heat transfer via the ground - Calculation methods, (2007).

[25] S.-I. Gustafsson, Optimal energy retrofits on existing multi-family buildings, Linköping studies in science and technology. Dissertation No. 0280-7971; 91. Linköping University, Sweden, 1986.

[26] S.-I. Gustafsson, Optimisation and simulation of building energy systems, Applied Thermal Engineering. 20 (2000) 1731-1741. doi:10.1016/S1359-4311(00)00004-1.

[27] S.I. Gustafsson, Optimal fenestration retrofits by use of MILP programming technique, Energy and Buildings. 33 (2001) 843-851. doi:10.1016/S03787788(01)00065-2.

[28] S.-I. Gustafsson, Mixed integer linear programming and building retrofits, Energy and Buildings. 28 (1998) 191-196. doi:10.1016/S0378-7788(98)00019-X.

[29] L. La Fleur, P. Rohdin, B. Moshfegh, Energy renovation versus demolition and construction of a new building - A comparative analysis of a Swedish multi-family building 1 Introduction, Energies. 12 (2019). doi:doi:10.3390/en12112218.

[30] L. Liu, A systematic approach for major renovation of residential buildings, Linköping 
studies in science and technology. Dissertation No. 1860, 2017. Linköping University, Sweden, Linköping, 2017.

[31] V. Milić, K. Ekelöw, M. Andersson, B. Moshfegh, Evaluation of energy renovation strategies for 12 historic building types using LCC optimization, Energy and Buildings. 197 (2019) 156-170. doi:10.1016/J.ENBUILD.2019.05.017.

[32] S.-I. Gustafsson, A Computer Model for Optimal Energy Retrofits in Multi-Family Buildings, Swedish Council for Building Research, 1990.

[33] S.-I. Gustafsson, The OPERA Model: optimal energy retrofits in multi-family residences, Linköping studies in science and technology. Dissertation No. 180, 1988. Linköping University, Sweden, 1988.

[34] N. Fumo, A review on the basics of building energy estimation, Renewable and Sustainable Energy Reviews. 31 (2014) 53-60. doi:10.1016/j.rser.2013.11.040.

[35] E.M. Ryan, T.F. Sanquist, Validation of building energy modeling tools under idealized and realistic conditions, Energy and Buildings. 47 (2012) 375-382. doi:10.1016/j.enbuild.2011.12.020.

[36] P. De Wilde, Building Performance Analysis, John Wiley \& Sons, Inc., 2018.

[37] D. Coakley, P. Raftery, M. Keane, A review of methods to match building energy simulation models to measured data, Renewable and Sustainable Energy Reviews. 37 (2014) 123-141. doi:10.1016/j.rser.2014.05.007.

[38] Equa Simulation AB, Technical Report: Validation of IDA Indoor Climate and Energy 4.0 build 4 with respect to ANSI/ASHRAE Standard 140-2004, Solna, Sweden, 2010. http://www.equaonline.com/iceuser/validation/ASHRAE140-2004.pdf.

[39] Equa Simulation AB, Technical report: Validation of IDA Indoor Climate and Energy 4.0 with respect to CEN Standards EN 15255 -2007 and EN 15265-2007, Solna, Sweden, 2010. http://www.equaonline.com/iceuser/validation/CEN_VALIDATION_EN_15255_A ND_15265.pdf.

[40] S. Kropf, G. Zweifel, Validation of the Building Simulation Program IDA-ICE According to CEN 13791 "Thermal Performance of Buildings - Calculation of Internal Temperatures of a Room in Summer Without Mechanical Cooling - General Criteria and Validation Procedures," Hochschule Technik+Architektur Luzern. HLK Engineering, 2001. http://www.equaonline.com/iceuser/validation/ICE_vs_prEN 13791.pdf.

[41] P. Loutzenhiser, H. Manz, G. Maxwell, Empirical Validations of Shading/Daylighting/Load Interactions in Building Energy Simulation Tools, A Report from the International Energy Agency's SHC Task 34/ECBCS Annex 42 Project C, 2007. http://www.equaonline.com/iceuser/validation/IEATask34.pdf.

[42] T.A. Reddy, Literature review on calibration of building energy simulation programs, ASHRAE Transactions. 112 (2006) 226-240.

[43] Sveby, Brukarindata bostäder, (2012). http://www.sveby.org/.

[44] Swedish National Board of Housing Building and Planning, Energi i bebyggelsen tekniska egenskaper och beräkningar, Karlskrona, Sweden., 2010. https://www.boverket.se/sv/om-boverket/publicerat-av- 
boverket/publikationer/2011/energi-i-bebyggelsen---tekniska-egenskaper-ochberakningar/.

[45] K. Difs, M. Bennstam, L. Trygg, L. Nordenstam, Energy conservation measures in buildings heated by district heating - A local energy system perspective, Energy. 35 (2010) 3194-3203. doi:10.1016/j.energy.2010.04.001.

[46] G. Verbeeck, A. Cornelis, Renovation versus demolition of old dwellings Comparative analysis of costs, energy consumption and environmental impact, PLEA2011 - 27th International Conference on Passive and Low Energy Architecture. (2011) 1-6.

[47] Wikells Byggberäkningar AB, Kalkylprogram och kalkylböcker inom Bygg, El och VVS - Wikells Byggberäkningar, (2018). http://www.wikells.se/omwikells.aspx.

[48] ASHRAE, IDA ICE Climate file - Linköping Malmslätt, Sweden, ASHRAE International Weather Files for Energy Calculations 2.0 (IWEC2), 2016.

[49] Swedish National Board of Housing Building and Planning, Building Regulations BFS 2011:6 with amendments 2017:5, Karlskrona, Sweden., 2017. https://www.boverket.se/sv/lag--ratt/forfattningssamling/gallande/bbr---bfs-20116/.

[50] Energiföretagen, Fjärrvärmens lokala miljövärden, (2017). https://www.energiforetagen.se/statistik/fjarrvarmestatistik/miljovardering-avfjarrvarme/.

[51] Swedish Energy Agency, Värmepumparnas Roll På Uppvärmningsmarknaden, 2015. https://energimyndigheten.a-w2m.se/Home.mvc?ResourceId=3044.

[52] Swedish Energy Agency, District heat price, SEK/MWh, (2019). http://pxexternal.energimyndigheten.se/pxweb/sv/Trädbränsle- och torvpriser/Trädbränsle- och torvpriser/EN0307_4.px/?rxid=17490455-e6ac-420d9379-57a19fe21658 (accessed June 24, 2019). 